NBER WORKING PAPER SERIES

\title{
MEDIEVAL UNIVERSITIES, LEGAL INSTITUTIONS, AND THE COMMERCIAL REVOLUTION
}

\author{
Davide Cantoni \\ Noam Yuchtman \\ Working Paper 17979 \\ http://www.nber.org/papers/w17979
NATIONAL BUREAU OF ECONOMIC RESEARCH
1050 Massachusetts Avenue
Cambridge, MA 02138 \\ April 2012
}

Helpful and much appreciated suggestions, critiques and encouragement were provided by Alberto Alesina, Regina Baar-Cantoni, Robert Barro, Claudia Goldin, Avner Greif, Elhanan Helpman, Lawrence Katz, James Robinson, Andrei Shleifer, Holger Spamann, Jan Luiten van Zanden, Jeff Williamson, by participants in the Economic History Association meeting in New Haven, the European Economic Association meeting in Milan, the SITE Summer Workshop 2010 and seminars at Berkeley, Harvard, Hong Kong University of Science and Technology, Oxford, Santa Clara, Universitat Autònoma de Barcelona, and Yale. The views expressed herein are those of the authors and do not necessarily reflect reflect the views of the National Bureau of Economic Research.

NBER working papers are circulated for discussion and comment purposes. They have not been peerreviewed or been subject to the review by the NBER Board of Directors that accompanies official NBER publications.

(C) 2012 by Davide Cantoni and Noam Yuchtman. All rights reserved. Short sections of text, not to exceed two paragraphs, may be quoted without explicit permission provided that full credit, including (C) notice, is given to the source. 
Medieval Universities, Legal Institutions, and the Commercial Revolution

Davide Cantoni and Noam Yuchtman

NBER Working Paper No. 17979

April 2012

JEL No. I25,N13,N33,O10

\begin{abstract}
$\underline{\text { ABSTRACT }}$
We present new data documenting medieval Europe's "Commercial Revolution" using information on the establishment of markets in Germany. We use these data to test whether medieval universities played a causal role in expanding economic activity, examining the foundation of Germany's first universities after 1386 following the Papal Schism. We find that the trend rate of market establishment breaks upward in 1386 and that this break is greatest where the distance to a university shrank most. There is no differential pre-1386 trend associated with the reduction in distance to a university, and there is no break in trend in 1386 where university proximity did not change. These results are not affected by excluding cities close to universities or cities belonging to territories that included universities. Universities provided training in newly-rediscovered Roman and Canon law; students with legal training served in positions that reduced the uncertainty of trade in medieval Europe. We argue that training in the law, and the consequent development of legal and administrative institutions, was an important channel linking universities and greater economic activity.
\end{abstract}

\author{
Davide Cantoni \\ Seminar für Wirtschaftsgeschichte \\ University of Munich \\ 80539 Munich \\ Germany \\ cantoni@lmu.de \\ Noam Yuchtman \\ Haas School of Business \\ University of California, Berkeley \\ Berkeley, CA 94720 \\ and NBER \\ yuchtman@haas.berkeley.edu
}




\section{Introduction}

The late Middle Ages saw the first stirrings of the "Rise of the West." ${ }^{1}$ Between the years 900 and 1500, Europe experienced a Commercial Revolution and awoke from centuries of economic slumber, with cities growing and trade expanding. This flowering of the European economy set the stage for modern Europe's exploration and colonization of the world, and its institutional and political development on the path toward modern growth.

Economic historians have documented this story of remarkable change using a variety of sources: from the rise of fairs (Epstein, 2000), to the physical expansion of cities (Verhulst, 1999), the increased output of books (Buringh and van Zanden, 2009), or the growth of population and urbanization (McEvedy and Jones, 1979; Bairoch et al., 1988). While informative, the existing data on the Commercial Revolution are often limited in their frequency, in their geographic coverage, or in their ability to capture economic change directly, making them difficult to use for identifying the causal factors that transformed Europe from a poor, rural, backward society (relative to the Chinese and Islamic civilizations), into an urban and commercial one. ${ }^{2}$

The Middle Ages saw not only economic transformation in Europe, but also the establishment of the first universities-first in Bologna in the 11th century, then fifty more in the following four centuries - and the development of formal legal institutions and state administrative systems. In this paper we consider the causal role that educational and legal institutions may have played in promoting economic activity.

The importance of institutional change has been highlighted by many scholars: Greif (1994), building on his analysis of informal arrangements among Maghribi traders (Greif, 1989, 1993), discusses the role of formal institutions for supporting the larger-scale economic exchange that occurred in late medieval Europe. De Long and Shleifer (1993) emphasize the importance of constraints on executives, which were developed in some of the new city-states that arose in the

\footnotetext{
${ }^{1}$ See, for example, Lopez (1976), North and Thomas (1973), Buringh and van Zanden (2009).

${ }^{2}$ Morris (2010), among others, ranks China's economic development in the Song Dynasty (960-1279 A.D.) ahead of Europe's and Mokyr (1990, ch. 9) explicitly compares Chinese and European technologies, noting China's "technological supremacy" in the Middle Ages (p. 209). Bosker and van Zanden (2008) compare urbanization rates between Western Europe and the Arab world, and show that they were much higher in the latter until the late Middle Ages.
} 
Middle Ages. Epstein (2000) similarly points to important administrative changes underlying the expansion of commercial activity. Van Zanden (2009) follows Berman (1983) in arguing that the development of European legal systems in the Middle Ages set the stage for Europe's political and economic development. Finally, Huff (2003) argues that the European university was an institution that was uniquely suited to promoting technical change, and that the rise of universities can be seen as an important institutional turning point in the history of European science. ${ }^{3}$

Existing work on medieval Europe has presented rich historical descriptions of the association between institutional and economic change, but has seldom been able to test for the presence of a causal link. ${ }^{4}$ North and Thomas $(1973$, p. 12), while clearly viewing institutional change as a crucial causal factor in Europe's economic development, make it clear how difficult it is to disentangle the relationship between institutions and economic growth in the Middle Ages, writing: “The revival of trade and commerce in the eleventh and twelfth centuries led not only to the proliferation of towns but to a host of institutional arrangements designed to reduce market imperfections. As new towns developed their own governments for administration and protection, they necessarily evolved bodies of law to adjudicate disputes arising from these new conditions." The institutions that reduced market imperfections and increased trade in the Middle Ages were likely both cause and consequence of increased economic activity.

The first purpose of this paper is to address the paucity of direct, systematic and quantitative evidence on the timing and spread of the Commercial Revolution. We present data on the establishment dates of 2,256 German ${ }^{5}$ cities, as well as the dates when these cities received grants to hold markets. The grants to hold markets are direct indicators of increased economic activity; the markets established under the grants took a variety of forms, and they were granted to cities large

\footnotetext{
${ }^{3}$ At the same time, it is clear that factors other than institutional change were also important to Europe's economic revival: for example, Mokyr (1990, ch. 3) discusses the important technological improvements that took place in the Middle Ages, and Morris (2010) focuses on climate change-the Medieval Warm Period-that made agriculture more productive.

${ }^{4}$ Some scholars have argued that no sustained increases of income per capita occurred before 1800 (Clark, 2007). Still, even in a Malthusian world economic change is of great interest, as it may indicate an out-of-equilibrium period of higher income, or a transition to a new, higher-income equilibrium. In addition, institutional and economic changes in the Middle Ages may have had persistent consequences (see, e.g., Acemoglu et al., 2005).

${ }^{5}$ The modern state of Germany did not exist in the period under consideration; our data cover the regions of Germany within its 1937 borders (excluding East and West Prussia, which were not considered part of the Holy Roman Empire). For brevity, we use the anachronism "Germany" throughout the paper.
} 
and small. This dataset thus captures economic changes in medieval Europe that occurred inside and outside large, urban areas, spanning a large region, over a long period of time.

The second, and primary, purpose of this paper is to test whether universities had a causal role in explaining increased economic activity in medieval Europe. Our data on market establishment in Germany throughout the Middle Ages allow us to test the role of universities in encouraging economic activity due to a unique natural experiment: Church politics—the Papal Schism of the late 14th century—resulted in the arguably exogenous foundation of Germany's first universities.

We outline a simple model linking human capital to market establishment, which generates an estimating equation and clear predictions regarding market establishment in Germany around the time of the Schism. In particular, we predict that there should be an increase in the trend rate of market establishment after the first German university was established in 1386, and that this break in the trend should be greater in cities with greater reductions in distance to a university.

We test these predictions using our data on market establishment and find strong support for them across a broad range of specifications. There is a significant positive break in the trend rate of market establishment in Germany in 1386; moreover, the break is larger in areas experiencing greater reductions in distance to a university. Importantly, there is no differential pre-1386 trend associated with the reduction in distance to a university, and there is no break in the trend rate of market establishment in 1386 where university proximity did not change. We check whether there is evidence of trend breaks in years other than 1386 and find that our findings are quite specific to the time when universities were first established. We also find that our results are robust to alternative time periods of analysis and to different definitions of our outcome variable.

While the timing of the Schism is plausibly exogenous with respect to economic conditions, the locations where the first universities were established are not. We thus examine whether endogenous university establishment might explain our results. We drop all cities within $20 \mathrm{~km}$ or $50 \mathrm{~km}$ of universities, and we use information on the identity of each city's ruling lord to drop cities in the same territory as a university. Again, our results are unaffected. We also consider regional differences between cities experiencing an increase in access to a university in 1386 and those that do not, dropping cities close to the Rhine and cities east of the Elbe. Finally, we consider 
the possibility that the Schism might have affected economic activity through channels other than university establishment. To do so, we examine market establishment in England and Italy, where the Papal Schism did not lead to the creation of new universities. We do not see changes in the rate of market establishment in either of these contexts.

Germany's first universities may have affected trade through several channels, but we present historical evidence indicating that the role of universities in developing legal and administrative institutions was likely an important one: universities trained lawyers, who became administrators, codified laws and regulations, and staffed and guided others through the legal systems that they helped to develop. ${ }^{6}$ Our analysis of the institutional environment of late medieval Germany, of the introduction of Roman legal thinking in that period, and of the careers of university-trained jurists supports this view.

We proceed as follows. In Section 2, we provide an overview of the Commercial Revolution, presenting data collected by other scholars that point to a dramatic change in Europe's economy, and presenting our newly-collected data on economic change in late medieval Germany. In Section 3, we describe how the Papal Schism can be seen as an exogenous shock leading to the foundation of new universities, and derive our empirical strategy. In Section 4 we use our data on market establishment to test for a causal effect of the new universities on commercial activity. In Section 5, we present historical evidence of the strong link between medieval universities and the development of formal legal systems in Europe, and argue that these legal systems played an important role in supporting economic activity in medieval Germany. In Section 6, we discuss our findings and offer some concluding thoughts.

\footnotetext{
${ }^{6}$ Murphy et al. (1994) argue that more lawyers are not always beneficial for growth, but we find it plausible that a small number of lawyers can be economically useful.
} 


\section{Documenting the Commercial Revolution}

\subsection{Existing Evidence}

Beginning around the tenth century, there was a revival of trade within the European continent and growth of trade with nations outside Europe. ${ }^{7}$ Increased trade and improved farming technology (which produced agricultural surpluses) allowed for larger urban populations. Robert Lopez (1976, p. 56) describes the Commercial Revolution as follows: "When food surpluses increased, it became possible to release more people for governmental, religious, and cultural pursuits. Towns re-emerged from their protracted depression. Merchants and craftsmen were able to do more than providing a fistful of luxuries for the rich."

Unfortunately, only very limited data for the period are available to support this grand narrative. To compare economic development across European regions during the Middle Ages, Buringh and van Zanden (2009) rely on the fraction of a region's population living in cities with populations greater than 10,000 and on manuscript production. Each should be correlated with the volume of economic activity: higher urbanization rates depend on trade, as goods must move from the country to the city; manuscript production would have been greater when incomes were higher and the demand for books (a luxury) was greater. ${ }^{8}$ In Figure 1, we present Buringh and van Zanden's (2009) data on these indicators of economic activity. They clearly reveal the dramatic changes experienced in Europe between the years 900 and 1500: in 900, Western Europe had only about $1 \%$ of its population living in cities with more than 10,000 people; by 1500 , the urbanization rate for Western Europe stood at over 8\%, with peaks of over $10 \%$ and $20 \%$ in the Netherlands and in Belgium, respectively. Similarly, manuscript production soared in the late Middle Ages, rising from less than 100,000 manuscripts per century to over 4 million.

In fact, aggregate urbanization figures for Western Europe conceal regional variations. Figure 2 plots urbanization rates for four European regions, Italy, France, the Netherlands (including

\footnotetext{
${ }^{7}$ After the decline of the (Western) Roman Empire (in 476), there was little trade throughout Western Europe. There seems to have been a revival of economic activity in the Carolingian Empire, but it was not sustained. See van Zanden (2009).

${ }^{8}$ De Long and Shleifer (1993) use city growth as a measure of economic development, and Acemoglu et al. (2005) and Acemoglu et al. (2011) use urbanization rates.
} 
Belgium), and Germany. While Italy took off early in the 11th and 12th centuries, and remained at a stable level of $13 \%$ urban population afterwards, France had a smoother path of moderate increases in urbanization rates. By this measure, Germany's urbanization rate remained constant at 5\% during the period 900-1500, whereas Belgium and the Netherlands increased their share of urban population strongly and consistently over time.

[Figure 1 about here]

[Figure 2 about here]

The data presented in Figures 1 and 2 match the narrative presented above: Europe changed dramatically between 900 and 1500. Yet, the data presented are only partially reflective of economic activity; moreover, they are extremely coarse measures of economic change, available only at long time intervals, and they completely ignore the developments that likely affected most Europeans at the time: the establishment of local markets and incorporation of smaller towns and cities. $^{9}$

\subsection{New Evidence on the Commercial Revolution in Germany}

The Deutsches Städtebuch, a series of volumes edited by Erich Keyser (1939-1964), compiles, for all of Germany, information on each incorporated city, including the date it was first mentioned, the date it was formally incorporated, and the dates when it received one or more "market privileges" from the Emperor or a local lord to hold markets and fairs. ${ }^{10}$ The market privilege was an official document that gave a local lord the right to tax trade in a formal market, to coin money and to require its use in the market; in exchange for these rights, it required the lord to guarantee the protection of merchants en route to, and present at, the market-this included the provision of courts and the establishment of standard measures. ${ }^{11}$

\footnotetext{
${ }^{9}$ Epstein (2000, p. 74) notes that "[t]he daily and weekly markets where most small-scale retailing took place" are often ignored by scholars.

${ }^{10}$ To be included, a "city" must have been incorporated prior to the compilation of the Städtebuch; the sizes of these cities today vary greatly from several hundred inhabitants to millions. Missing information, and uncertainty regarding some dates are undeniable problems. However, it is generally clear when there is such uncertainty, and we do not include in our analysis market or city establishments whose dates are uncertain.

${ }^{11}$ Epstein (2000, p. 82); Britnell (1978, p. 192); Schmieder (2005, p. 49).
} 
Of course, the use of market grants as an indicator of market activity is imperfect; it might, in some instances, indicate changes in the formality of economic institutions, rather than changes in economic activity itself. That is, improvements in a state's capacity to tax trade and protect merchants, or an increased desire or ability to formally structure economic activity, may have led to an increase of market grants, even if economic activity had not changed. However, we treat the granting of a market privilege as an event marking market establishment. The work of historians of medieval Europe studying such grants supports the view that royal charters were often associated with the actual creation of new markets, and were not simply the formal recognition of existing ones. ${ }^{12}$

For all 2,256 cities in the Deutsches Städtebuch, we collected data on their date of incorporation, and on all of the years in which they were granted one or more market privileges, throughout the Middle Ages. The spatial distribution of these cities within Central Europe is displayed in Figure 3. This information provides direct evidence of the establishment of hundreds of cities and markets during the Middle Ages.

\section{[Figure 3 about here]}

In Figure 4 we show the number of city incorporations and market establishments. The top graph displays absolute numbers of incorporations and market grants in 10-year moving averages; the bottom graph displays the cumulative number of cities incorporated or markets established at each point in time. The figure reveals a dramatic rise in city incorporations in the German lands in the 13th century; the average number of cities incorporated per year increased from less than one to approximately four. The granting of market rights also accelerated during the 13th century, albeit considerably more slowly. During the 14th century, the comovement of city incorporations and market grants becomes evident, indicating a clear tendency toward both greater urbanization and expanded economic activity, a tendency which is not even reversed by the arrival of the Black Death of 1348 . Toward the end of the 14th century, however, the two series begin to diverge. City incorporations subside, while the number of markets granted per year remains

\footnotetext{
${ }^{12}$ Britnell (1981, p. 211) discusses the case of England; Epstein (2000) uses legal documents as indicators of economic activity in Italy.
} 
high, varying between approximately 2-6 markets per year.

[Figure 4 about here]

Importantly, the trends displayed in Figure 4 are not limited to large urban areas, but are experienced much more broadly, reflecting economic activity and urbanization over the whole of Germany. The contrast between our city establishment time series with Buringh and Van Zanden's (2009) urbanization data for Germany is quite striking: from a comparison of Figures 2 and 4, one can see that while the proportion of Germans living in large cities (over 10,000 inhabitants) was not increasing throughout the 13th and 14th centuries, hundreds of smaller cities were being established at that time. Markets were being regularly established as well, indicating a much more dynamic German economy at the time than would be inferred from simply looking at the urbanization rates.

\section{Universities and Market Establishment}

\subsection{Universities and the Commercial Revolution}

At precisely the time when it experienced its Commercial Revolution, Europe also saw the creation of its first universities. ${ }^{13}$ The first university, the University of Bologna, was founded in the eleventh century by foreign students who were receiving training in the law: the Justinian Code of Roman civil law had just been rediscovered at this time, and Bologna had become a preeminent site of legal scholarship. Students in Bologna, many of them foreigners, formed a corporation of scholars (universitas) to obtain official recognition and protection of their rights.

Universities spread rapidly throughout Europe during the period of the Commercial Revolution. There were no universities in all of Europe before the Commercial Revolution began in the tenth century. By the year 1500, there were more than 50 (Verger, 1992, pp. 62-65). In Table 1, we provide a list of some of the universities founded in the Middle Ages, along with their foundation dates.

\footnotetext{
${ }^{13}$ Good references on the medieval universities include Rashdall (1895) and DeRidder-Symoens, ed (1992).
} 
These medieval universities may have supported economic activity during the Commercial Revolution through a variety of channels: first, they generated increased human capital: training in the liberal arts was comprised of logic, grammar and rhetoric (the trivium) as well as arithmetic, geometry, music, and astronomy (the quadrivium), skills that may have been commercially useful. Second, they encouraged the formation of networks of individuals who were mobile, who spoke Latin, and who were trained in common subjects, using common texts. Perhaps most importantly, medieval universities trained a large number of individuals in canon and civil law. ${ }^{14}$ This specific type of human capital was especially important in medieval Europe, where the development of merchant, administrative and civil law, the staffing of courts, and the enforcement of contracts was critical to solving the "fundamental problem of exchange" (Greif, 2000): the resolution of uncertainty in economic transactions due to highly disaggregated political institutions, high costs of transportation and communication, and thus high risk of expropriation by the state or by one's agent. $^{15}$

Of course, the development of legal and educational institutions was very much a response to improving economic conditions-this was certainly true of medieval universities. Without identifying a source of exogenous variation in the establishment of universities, it is difficult to credibly establish a causal link between them and increased economic activity.

\subsection{The Papal Schism as a Natural Experiment in University Establishment}

The Papal Schism of 1378 represents a source of variation in the creation of universities the timing of which was arguably exogenous with respect to the German economy. We thus focus on the period around the Schism to identify universities' contribution to Germany's economic development; we argue that this natural experiment can be used to credibly identify the causal effect of

\footnotetext{
${ }^{14}$ Swanson (1985, p. 29) is skeptical of the value of university training in the Middle Ages writing, "Of all the institutions of the medieval church the universities were perhaps the most parasitic." Yet, the object of his criticism is the English universities' training of clerics. He views training in the law, which in England occurred in the Inns of Court, quite differently (p. 30). See also Cobban (1975, pp. 220-224), on the practical value of university study.

${ }^{15}$ See Greif $(1993,2000,2006)$, Greif et al. (1994), and van Zanden (2009) for discussions of the institutions developed to solve problems of insecure property rights and uncertain contract enforcement in the Middle Ages.
} 
university establishment on economic activity.

Prior to the establishment of the first German university in 1386, German students had to travel abroad, to the universities of Paris, Bologna, Prague, or other cities, to receive a university education. ${ }^{16}$ However, by 1392, there were three universities in Germany: one in Heidelberg (founded in 1386), one in Cologne (1388), and one in Erfurt (1392). ${ }^{17}$ In a brief period of time, the distance to a university - and so the cost of university attendance-shrank significantly for individuals across Germany. The shade of city markers on the map in Figure 3 indicates the change in distance to a university that resulted from the new universities' establishment (darker colors indicate a larger change in distance). The reason for the sudden foundation of several German universities was the Papal Schism. ${ }^{18}$

From 1309 to 1378, a period known as the "Avignon Papacy," popes resided in Avignon, France, rather than in Rome. In 1378, Pope Gregory XI moved the Papal Court back to Rome, and died shortly thereafter. The election to replace Gregory XI resulted first in the selection of Pope Urban VI, who remained in Rome, and then in the selection of (antipope) Clement VII, who maintained his court in Avignon. Thus, beginning in 1378, there were two rival popes; secular lords chose to pledge allegiance to one or the other. France and Spain were loyal to the French pope, while the Holy Roman Empire and the Italian states were loyal to Rome. ${ }^{19}$

The split in the Church had important consequences for university students and faculty from Germany. Because there were no German universities, many of them had studied and taught at French universities, such as the universities of Paris and Orléans. However, following the Schism (especially after the declaration in support of Clement VII in February 1383), the University of Paris did not tolerate individuals loyal to the Roman pope, as were German students and fac-

\footnotetext{
${ }^{16}$ Prague was part of the Holy Roman Empire. However, in following the convention of this paper, we use the anachronism "German" to refer only to the territory covered by our dataset, which does not encompass Prague and the Kingdom of Bohemia.

${ }^{17}$ Another university of the Holy Roman Empire, the University of Vienna, was officially established in 1365, but actual teaching there did not begin until after the Schism (in 1383). At that time, the famous theologian Henry of Langenstein arrived from the University of Paris and attracted the students necessary for the university to function. In addition, the University of Leipzig was founded in 1409.

${ }^{18}$ While the precise timing of the Papal Schism was arguably exogenous with respect to the development of the German economy, the location of universities established following the Schism may likely be correlated with other determinants of economic activity. We examine this issue in detail below (see section 4.2, Table 4).

${ }^{19}$ Some exceptions to this pattern are described in Swanson (1979).
} 
ulty. Forced to leave the French universities, students and faculty returned to Germany, where universities were established to take them in. ${ }^{20}$ Roman popes were willing to grant bulls for the foundation of new universities as a means of weakening the theological monopoly held by the faculty of Paris, now affiliated with the Avignon pontiffs (Rashdall, 1895, p. 247).

Notable faculty who were forced to return to the Holy Roman Empire by the Schism, such as Marsilius of Inghen, who taught at the University of Heidelberg, attracted students to the new universities. The decreased cost of university attendance did so as well. Rashdall (1895, p. 214) wrote,

"The bulk of Germans at foreign universities [before the Schism] were probably young nobles and well-born or well-beneficed ecclesiastics. ... The career open to merit was [after the Schism] brought within reach of sons of the tradesmen and the artisan. Martin Luther could have hardly enjoyed a university education if he had had to go to Paris for it."

Thus, as a result of the Papal Schism, Germany was rapidly transformed from a land with no universities, and relatively few graduates, into a land with several universities and many graduates. ${ }^{21}$ Importantly, the cause of this transformation was not economic: the Papal Schism was a political event that did not coincide with any dramatic economic shifts of which we are aware. In Table 2, we list several important economic changes that affected Germany in the centuries surrounding the Papal Schism: important institutional innovations, discoveries of precious metals, and the massive demographic shock of the Black Death were all important events that did not coincide with the Papal Schism (we further examine whether the Schism affected economic activity through channels other than university establishment in Table 6).

\section{[Table 2 about here]}

The source of variation represented by the Papal Schism and its effect on university establishment allows us to attempt to make a causal inference regarding the role played by universities

\footnotetext{
${ }^{20}$ Swanson (1979) discusses the debates within the university of Paris that eventually led to the exodus of German academics.

${ }^{21}$ An important question regarding the rise in the number of German graduates is why there was no university establishment before the Schism, given the apparent demand. One possible reason is that the Church wanted to limit the number of centers of theological and canon law training to prevent heterodox teachings. This constraint was loosened by the Schism, because the Roman Church lost the University of Paris, which had been the preeminent university for the study of theology until then.
} 
in promoting economic activity in the Middle Ages. Of course, one may wonder about the external validity of the effect we estimate. We believe that the "local" treatment effect we identify in 14th century Germany is informative about the role played by universities and human capital in medieval Europe more generally. ${ }^{22}$

\subsection{A Simple Model of University Foundation and Market Establishment}

We now present a simple model that links university proximity, and thus human capital, to market establishment. It generates an empirical model of market establishment that we estimate below, as well as clear predictions regarding the effects of the Papal Schism and the subsequent establishment of Germany's first universities on economic activity.

Our hypothesis is that medieval universities increased human capital in areas in closer proximity to them. This human capital, in turn, was important for supporting markets. In section 5, below, we argue that training in newly-rediscovered Roman and canon law was especially useful. In the current model, we do not make any specific assumption about what sort of human capital was useful, and argue only that having a university in close proximity increased human capital, and thus the likelihood of establishing a market.

We model market establishment in medieval Germany as a function of (time-varying) underlying economic conditions that were common to all cities, as well as human capital, $h_{i, t}$, which was time-varying and city-specific. ${ }^{23}$ Because our focus is on market establishment in a relatively narrow window of time around the establishment of Germany's first universities, we approximate changing economic conditions with a simple time trend. If we assume an additive, separable relationship between the time trend and human capital, we can write the market establishment function as follows:

$$
\text { markets }_{i, t}=\alpha_{1} \cdot \text { Year }_{t}+\gamma \cdot h_{i, t}
$$

\footnotetext{
${ }^{22}$ It is also worthwhile to state explicitly that the question underlying this paper is whether universities played some causal role in increasing economic activity in the Middle Ages-as also evident from the fact that markets grants had been flourishing in Germany already before the Papal Schism (see Figure 4)-rather than playing the ultimate causal role in driving all economic change in the period.

${ }^{23}$ As an additional robustness check, we also consider region-specific time trends in our empirical work (see the online appendix, Table A.1).
} 
Human capital is a stock: it will depend on the cumulative effect of access to education in the past. In medieval Germany, a crucial determinant of access to the human capital produced in universities was the distance to the nearest university. Thus, we model the human capital stock in a city at any time as a (negative) linear function of the distance of that city to the nearest university in $n$ past years:

$$
h_{i, t}=-\sum_{j=1}^{n} \delta_{t-j} \cdot \text { distance }_{i, t-j}
$$

Prior to the Papal Schism and the establishment of the University of Heidelberg in 1386, German students attended university abroad; there was a stable value of distance $_{i, t-j}$, and so a stable level of human capital. ${ }^{24}$ After the foundation of the University of Heidelberg, cities experienced a reduction in distance to a university. We define the following:

$$
\Delta \text { DistUniv }_{i}=\text { distance }_{i, \text { pre }}-\text { distance }_{i, p o s t},
$$

where distance $_{i, p r e}$ represents the pre-Schism minimum distance from city $i$ to a university; we will measure it in our empirical section as the minimum of the distance to the universities operating as of 1385 (Bologna, Paris, Prague, etc.). The post-Schism distance to a university, distance $_{i, p o s t}$, is computed as the minimum of distance $_{i, p r e}$ and the distance to one of the newly founded German

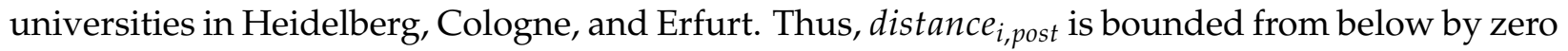
in the case of all cities that, following the Schism, were no nearer to a university city than before. ${ }^{25}$

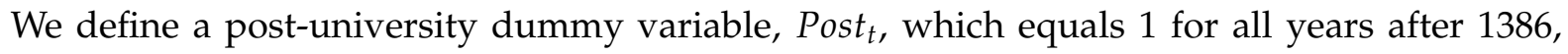
and a linear time trend Year ${ }_{t}$, normalized to be 0 in the "pivot year" of $1386 .{ }^{26}$ As derived in the

\footnotetext{
${ }^{24}$ This is, of course, only approximately true, and only a good approximation for short time periods $n$.

${ }^{25}$ For all city-years it beginning in 1386, we treat distance to a university as the post-Schism distance. Treating different cities (or years) differently as a function of the timing of the two other post-Schism university establishments (Cologne and Erfurt) would raise concerns about endogeneity; hence, we calculate a single value of $\Delta D i s t U n i v$ for each city $i$, applied to all years, based on the three universities established between 1386 and 1392.

${ }^{26}$ The 8-year delay between the Schism itself and the foundation of the University of Heidelberg was due to the fact that the expulsion of German academics from French universities did not occur before 1381-1384, and to the time needed to grant a papal bull and set up a new institution of higher learning (Swanson, 1979, pp. 58-74).
} 
appendix, we obtain the following estimating equation:

$$
\begin{aligned}
& \text { markets }_{i, t}=\alpha_{0}+\alpha_{1} \cdot \text { Year }_{t}+\alpha_{2} \cdot \text { Post }_{t}+\alpha_{3} \cdot \text { Year }_{t} \cdot \text { Post }_{t}+\alpha_{4} \cdot \Delta \text { DistUniv }_{i} \\
& +\alpha_{5} \cdot \Delta \text { DistUniv }_{i} \cdot \text { Year }_{t}+\alpha_{6} \cdot \Delta \text { DistUniv }_{i} \cdot \text { Post }_{t} \\
& +\alpha_{7} \cdot \Delta \text { DistUniv }_{i} \cdot \text { Year }_{t} \cdot \text { Post }_{t}+\varepsilon_{i, t}
\end{aligned}
$$

Several terms on the right hand side are of special interest. First, the term on which we focus our hypothesis testing is $\Delta$ DistUniv $_{i} \cdot$ Year $_{t} \cdot$ Post $_{t}$ : it will indicate whether cities with a larger reduction in distance to a university experienced a changed trend rate of market establishment after 1386. If the Schism, and university establishment, had the hypothesized effects on market establishment, we expect this term to be positive and significant.

The Year ${ }_{t} \cdot$ Post $_{t}$ term will indicate whether cities not experiencing any change in distance to a university nonetheless experience a change in the trend rate of market establishment after 1386. This term will have explanatory power if the Schism affected market establishment even where it did not reduce distance to a university. If the Schism only affected market establishment rates through the change in distance to a university, this term should not be statistically significant.

The $\Delta$ DistUniv $_{i} \cdot$ Year $_{t}$ term also provides an important falsification test: it indicates whether cities with a large change in distance to a university had different trend rates of market establishment even before reduction in distance occurred. If $\Delta{\text { Dist } U n i v_{i}}_{i}$ is uncorrelated with economic conditions, then $\Delta$ Dist Univ $_{i} \cdot$ Year $_{t}$ should not be statistically significant. In standard differencein-differences terminology, the term provides a test of parallel trends in the rate of market establishment between cities that would and would not experience a change in distance to a university following the Schism.

Next, the $\Delta$ Dist Univ $_{i} \cdot$ Post $_{t}$ term tells us if there was an immediate jump in market establishment just in 1386 in cities that experienced a reduction in distance to a university. Our hypothesized channel of human capital accumulation affecting market establishment leads us to expect that term will not be statistically significant. The $\varepsilon_{i t}$ term will capture shocks to market establishment specific to a city-year; in our empirical work we allow these shocks to be correlated across 
observations for each city.

In addition to looking at the city-level panel data, we will take a more macro-level view of market establishment around the time of the establishment of the first German university. If we aggregate market establishments across cities in equation (3), we can examine time series variation in market establishment in all of Germany around 1386. Thus, we estimate:

$$
\text { markets }_{t}=\beta_{0}+\beta_{1} \cdot \text { Year }_{t}+\beta_{2} \cdot \text { Post }_{t}+\beta_{3} \cdot \text { Year }_{t} \cdot \text { Post }_{t}+\eta_{t}
$$

The dependent variable is the number of markets established in year $t$, divided by the number of cities ever established in the region considered (in this case, all 2,256 German cities in our dataset). ${ }^{27}$

Equation (4) examines whether there is a change in the trend rate of market establishment in the pivot year, 1386 (the coefficient on Year $_{t} \cdot$ Post $_{t}$ ), and whether there is a discrete jump in the market establishment rate (the coefficient on Post $_{t}$ ) at that time. If university establishment affected human capital accumulation, one would expect Year ${ }_{t} \cdot$ Post $_{t}$ to be positive and significant. Moreover, one would not expect Post $_{t}$ to be significantly different from zero, as this would imply an implausible, sudden effect on economic activity.

\section{Empirical Analysis}

\subsection{University Foundation and Market Establishment in Germany}

We begin our analysis by estimating equation (4) considering all of Germany from 20 years before through 20 years after 1386. The findings of Table 3, column 1, confirm the predictions of our model: there is a positive break in the trend rate of market establishment, and no discrete jump, in 1386. The predicted trends of market establishment pre- and post-1386 can be seen in Figure $5 .^{28}$

\section{[Table 3 about here]}

\footnotetext{
${ }^{27}$ In practice, we scale the data so that the outcome is the number of markets per thousand cities in the area studied.

${ }^{28}$ Figure 5 also shows that the change in trend after 1386 is not due to date heaping in the year 1400. In fact, Germany witnessed fewer market granting episodes in 1400 (2) than in the years 1399 or 1401 (4 and 9, respectively).
} 
[Figure 5 about here]

The magnitude of the coefficient on Year ${ }_{t} \cdot$ Post $_{t}, \hat{\beta}_{3}$, can be interpreted as 0.151 additional markets per thousand cities for every additional year after 1386; this effect is large enough to reverse the negative pre-trend (coefficient on $Y_{e a r}$ ) of -0.061 . The cumulative effect of this reversal in trends can be observed in Figure 5, and suggests a change from less than two markets per year established (per thousand cities) in 1386 to about three markets per year twenty years later.

We next wish to link reduced distance to a university to the change in the trend rate of market establishment. As a first approach, we simply divide our sample into two groups, based on the reduction in distance to the closest university, $\Delta$ Dist Univ. Equation (4) is then estimated separately for the sample of cities whose change in distance is above the median change, and the cities whose change is less than the median change. We expect a larger change in the trend rate of market establishment in the sample with large changes in distance to a university. Indeed, in Table 3, columns 2 and 3, one can see that the coefficient on Year ${ }_{t} \cdot$ Post $_{t}$ is positive and significant for the sample of cities with a large (above median) change in distance to a university, but not for regions with a small (below median) change in distance to a university. We plot the trends for these two regions in Figures 6 and 7.

[Figure 6 about here]

[Figure 7 about here]

To analyze the importance of the change in distance to a university in a more systematic way, we now turn to the city-level panel data and estimate equation (3). As noted above, if improved access to universities drove market establishment after 1386, one would expect to see a positive coefficient on the triple interaction term $\Delta$ DistUniv $_{i} \cdot Y_{\text {ear }} \cdot$ Post $_{t}$. At the same time, we should not see a significantly different pre-1386 trend rate of market establishment in places with larger changes in distance to a university (i.e., the coefficient on $\Delta \operatorname{DistUniv}_{i} \cdot Y_{e a r_{t}}$ ), nor should we see a significant change in the trend rate of market establishment in 1386 among cities with no change in distance to a university (i.e., the coefficient on $\mathrm{Year}_{t} \cdot$ Post $_{t}$ ). In Table 3, column 4, these predictions 
are confirmed: there is a significant, positive change in trend that is greater in cities experiencing a greater reduction in distance to a university, but no differential trends across these areas before 1386.

Our baseline panel specification used city-year level data. A concern could be that this choice, resulting in over 90,000 observations in our baseline specification, distorts our statistical inferences, although standard errors are clustered at the city level. In addition, there might be general equilibrium effects of market establishment: a market in one city may replace (or simulate the creation of) a market in another, meaning the units of observation might not have been independent. To gauge the importance of the choice of city-year as the unit of analysis, we aggregate our data to larger units of observation. Our outcome variable will be the number of markets established in a territorial lord's land in each year (normalized as a rate per 1,000 cities). ${ }^{29} \Delta$ Dist Univ $_{i}$ is now calculated as the average change in distance to a university across all cities in the relevant lord's territory.

Estimating equation (3) using territory-year level, instead of city-year level, data does not affect our results, nor our statistical inferences (see Table 3, column 5). Alternatively, we aggregate our market establishment data to the level of 1-degree by 1-degree latitude-longitude cells. Again, we find that areas experiencing a larger reduction in distance to a university experienced a greater positive break in the trend rate of market establishment after 1386 (see Table 3, column 6). In both of these alternative datasets, we find no evidence of a differential pre-trend in areas with greater reductions in distance to a university, nor do we find positive trend breaks in areas with no reduction in distance to a university. In the following regression tables, we will present results based on city-year level data; however, we replicate our panel regressions using territory-year and cell-year level data in the online appendix (Tables A.2 and A.3). ${ }^{30}$

An important concern with the above regressions is that the timing of university establishment in Germany following the Schism was possibly endogenous. In addition, our results in Table 3

\footnotetext{
${ }^{29}$ The Holy Roman Empire in the late Middle Ages was a complicated array of partly overlapping layers of sovereignty. For each city in our dataset we coded the highest liege lord (other than the Emperor) to which it was subject around 1386 .

${ }^{30} \mathrm{We}$ also report our city-year regressions with standard errors clustered at the territory level in the online appendix (Table A.4).
} 
might simply be capturing changes in trends that began before university establishment and that were more pronounced in areas that happened to experience reductions in distance to a university following the Papal Schism.

To examine the likelihood of either of these possibilities, we check whether alternative pivot years generate results similar to those above. These alternative pivot years can be thought of as placebo tests: we expect to see trend breaks (in the time series specification) and a significant triple interaction term $\Delta$ DistUniv $_{i} \cdot$ Year $_{t} \cdot$ Post $_{t}$ for pivot years around 1386, but not for other pivot years.

We thus estimate equation (4) 21 times on the full sample of cities; and we estimate equation (3) 21 times on the full city-year panel. In each regression, we use a 40-year window around every year between 1376 and 1396, changing the definition of Post $t_{t}$ accordingly. We plot the coefficients on Year ${ }_{t} \cdot$ Post $_{t}$ or $\Delta$ DistUniv $_{i} \cdot$ Year $_{t} \cdot$ Post $_{t}$, respectively, from these regressions, along with their $95 \%$ confidence intervals, in Figures 8 and $9 .{ }^{31}$ One can see that the largest, most significant trend breaks occur very close to 1386 . Ten years before Germany's first university was established, market establishment rates were not experiencing any sharp break in trend, as evidenced by the point estimate being close to 0 . Analogously, after 1386 there is progressively less evidence of a change in trend. The sharp change in the trend rate of market establishment is quite specific to the time of university establishment in Germany.

[Figure 8 about here]

[Figure 9 about here]

\subsection{Endogeneity of University Location}

The results above reveal a positive break in the trend in market establishment in 1386-when Germany's first university was established-and that this break in trend was most evident in areas that experienced the greatest reduction in the distance to a university during the Papal Schism. However, one might be concerned about the possibility that the location of universities, and thus

\footnotetext{
${ }^{31}$ The online appendix reports graphs analogous to Figure 8 for the two subsamples of cities with above and below median changes in distance to a university (Figures A.1 and A.2).
} 
$\Delta$ DistUniv $_{\text {, was }}$ correlated with an unobserved variable that also stimulated economic activity around the time of the Schism. For example, the results in Table 3 might have been due to a correlation between good leadership, or good local economic conditions, and university foundation. That is, a territorial lord may have founded a university, then founded many markets nearby; a prescient lord may have founded a university in anticipation of good economic times ahead. Alternatively, a positive local economic shock, leading to a surplus of agricultural goods, might have driven the founding of a university and market establishment in close proximity.

These alternative stories would explain a sharp change in market establishment rates precisely when universities were founded, and near those universities. ${ }^{32}$ To examine the possibility that our results in Table 3 were the result of endogenous university locations, we estimate our baseline specifications on alternative samples of German cities: first, we exclude cities within $20 \mathrm{~km}$ of a university, then those within $50 \mathrm{~km}$ of a university. Next, using information on local territorial lords collected for each of our cities from the Deutsches Städtebuch, we exclude from our analysis the three lords' territories containing a university city: these are the Rhenish Palatinate (Heidelberg), the Archbishopric of Cologne (Cologne), the and Archbishopric of Mainz (Erfurt).

In Table 4, columns 1, 3, and 5 one can see that there is a significant break in the trend rate of market establishment in 1386 even when we exclude cities within $20 \mathrm{~km}$ or $50 \mathrm{~km}$ of a university, or when we exclude cities in the same territory as a university. ${ }^{33}$ The role played by the reduction in distance to a university can be seen in the corresponding panel data specifications of Table 4, columns 2, 4, and 6: there is a positive and significant break in the trend rate of market establishment that is greater for cities with a larger change in distance to a university (see the coefficient on $\Delta$ DistUniv $_{i} \cdot$ Year $_{t} \cdot$ Post $\left._{t}\right)$. Importantly, we do not see any differential pre-1386 trend associated with $\Delta$ DistUniv $_{i}$, and we see no effect of the Schism on post-1386 market establishment in cities experiencing no change in distance to a university.

\section{[Table 4 about here]}

\footnotetext{
${ }^{32}$ Note that the results in Table 3 do not refer directly to the proximity of universities, but rather the change in proximity: the correlation between the change in distance to a university (as a result of the Schism) and the actual distance to the newly founded universities is -0.554 .

${ }^{33}$ The online appendix reports additional results separately for the samples of cities with above-median and belowmedian $\Delta$ DistUniv (Table A.5).
} 
Another concern about the location of universities is that cities with high values of $\Delta$ DistUniv are generally concentrated in Western Germany, close to the Rhine and near the economically vibrant Low Countries. Additionally, scholars have identified important institutional differences between Germany east and west of the Elbe following the Black Death of 1348 (e.g., Brenner, 1976; Dittmar, 2009). Thus, one wants to be sure that our results are not driven simply by our comparison of late 14th-century economic activity between these two regions. It is important, however, to point out that differences across German regions would much more likely explain

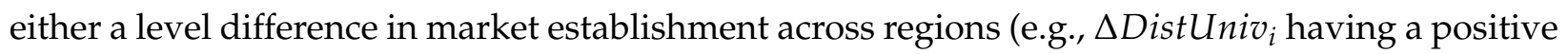
coefficient), or a different trend in market establishment (e.g., $\Delta$ Dist Univ $_{i} \cdot Y_{e a r_{t}}$ having a positive coefficient). It would be much more difficult to explain why there would be a positive break in the trend rate of market establishment precisely in 1386.

In Table 4, column 7, we test for a break in the trend rate of market establishment only on the sample of cities farther than $20 \mathrm{~km}$ from the Rhine. We continue to find a significant break in the trend. In column 8 one can see that this break is again greater in cities with greater reductions in distance to a university. Finally, columns 9 and 10 estimate analogous specifications for cities that are West of the Elbe; even in this restricted subsample, we continue to find very similar results (though the coefficient on $\Delta$ DistUniv $_{i} \cdot$ Year $_{t} \cdot$ Post $_{t}$ is now marginally insignificant, with a p-value of 0.102$){ }^{34}$

\subsection{Robustness of the Empirical Results}

We now examine whether our baseline results in Table 3 are robust to alternative specifications. We first consider changing the window of time around 1386 that we examine. In Table 5, columns 1 and 2, we replicate our estimates in Table 3, columns 1 and 4, but consider a \pm 15 year window, rather than a \pm 20 year window. We find even stronger results than in the baseline pe-

\footnotetext{
${ }^{34}$ As an additional robustness check, in the online appendix (Table A.1) we present results based on the panel data specification of equation (3), augmented by state-specific time trends, as well as interaction terms of Post $t_{t}$ and Year . $_{t}$. Post $_{t}$ with state dummies. (We adopt the division of Germany into 18 states operated by the volumes of the Deutsches Städtebuch; for the vast majority of cases, these states correspond to present-day Länder in the Federal Republic of Germany.) In this setup, the effect of a change in distance to a university on market establishment is estimated only from within-state variation of $\Delta$ DistUniv. All results are qualitatively similar to those reported in the main text.
} 
riod. If a time window of \pm 25 years is considered instead, one finds a positive, but insignificant break in the trend rate of market establishment, and a small, positive, insignificant coefficient on $\Delta$ DistUniv $_{i} \cdot$ Year $_{t} \cdot$ Post $_{t}$ (Table 5, columns 3 and 4). These results, especially the strong results for the narrower time window, are reassuring in their qualitative similarity to our findings in Table 3. In interpreting the weaker results in columns 3 and 4 , it is worth keeping in mind that we model market establishment across time using linear trends (and breaks in trends). As the time window under consideration becomes wider, it is more likely that other economic shocks are captured in the data, and that our linear approximation of trend rates (and breaks thereof) is less appropriate. ${ }^{35}$

\section{[Table 5 about here]}

We next consider variants of our outcome variable. In many cases, the incorporation of a city was explicitly linked to the creation of a market; if evidence of both could be found in the Städtebuch, this will be reflected both in our city incorporations and market grants data. But in some cases, no explicit mention of markets is made in the Städtebuch when a city incorporation is reported; to the extent that the city charters implicitly included the rights to hold a certain number of markets or fairs, therefore, our market grant data will underestimate the actual number of markets.

To check whether this ambiguity affects our results, we use the sum of the market establishments and city incorporations in a given year (or city-year) as the outcome variable. The results in Table 5, columns 5 and 6, again show a significant break in the trend rate of market establishment in 1386, and a greater positive trend break in areas with greater reductions in distance to a university. At the same time, there is now a marginally significant negative pre-1386 trend associated with distance to a university. This could raise concerns to the extent that one would like areas with greater reductions in distance to a university to be identical to areas with less. In practice, the negative trend in city incorporation (recall there was no significant trend in market establishment

\footnotetext{
${ }^{35}$ In fact, the R-squared is decreasing in the size of the window considered: in Table 5, column 1 ( \pm 15 year window), it is 0.167 ; in Table 3, column 4 (the \pm 20 year window), it is 0.098 ; in Table 5, column 3 ( \pm 25 year window), it is only 0.034 .
} 
itself) likely biases results against our hypothesis. ${ }^{36}$

The results above might be biased by a few instances of multiple market granting to a city (with high values of $\Delta$ DistUniv) in a given year. In Table 5, columns 7 and 8, we thus estimate our baseline specifications using an indicator of any market establishment (computed as a rate per 1,000 cities) as our outcome, rather than the total number of markets established in a city-year. Our estimated coefficients are slightly smaller, but we continue to see a positive, statistically significant break in trend that is greatest in areas with large reductions in distance to a university.

\subsection{Placebo Regressions: The Economic Impact of Papal Politics}

We next ask whether some effect of the Papal Schism other than university establishment was likely to have changed economic activity and caused some part of the trend break we found above. ${ }^{37}$ For example, the Schism may have affected trade patterns; shifts in papal politics may have had broader impacts on Western Christendom.

We thus examine market establishment trends in England/Wales and Italy, which were exposed to the Papal Schism, but which experienced no significant changes in the number of universities in the baseline period we study. ${ }^{38}$ If England and/or Italy experienced changes in market establishment rates in 1386, one would suspect that there were consequences of the Schism for economic activity that worked through channels other than university establishment.

Because we lack any cross-sectional variation in Italy and England analogous to $\Delta$ DistUniv in Germany, we simply test for breaks in the trend rate of market establishment in these regions in $1386 .{ }^{39}$ The results presented in Table 6, columns 1 and 2, indicate that there was no change in the level or trend of the rate of market establishment in Italy or England in 1386. The Schism did not affect market establishment rates in places that did not experience increased university

\footnotetext{
${ }^{36}$ If areas with high $\Delta$ Dist Univ had fewer cities established just before 1386, this may have meant fewer places where markets would then be granted after 1386 .

${ }^{37}$ Note that to account for the changes in market establishment found above, these other, unobserved economic effects would have had to be correlated with the reduction in distance to a university.

${ }^{38}$ The market establishment data we were able to collect for Italy are for Naples, Sicily, and Lombardy, and come from Mira (1955), Grohmann (1969), and Epstein (1992). The English and Welsh market data were collected by Keene and Letters (2004).

${ }^{39}$ Results are very similar if we use 1378, the year of the Schism itself, as the pivot year; these regressions are reported in the online appendix (Table A6).
} 
establishment as a result. This evidence strongly points to increased access to universities as the causal factor explaining increased rates of market establishment in Germany after 1386.

[Table 6 about here]

\section{Universities, Legal Training, and the Commercial Revolution}

How might the establishment of medieval universities have promoted the expansion of economic activity observed during the Commercial Revolution? We argue that the most important channel through which universities affected economic activity likely was the the education in Roman and canon law that they provided and the consequent development of legal institutions. The purpose of this section is to argue that, first, the number of individuals trained in law in Germany increased after the Schism; second, that the development of legal and administrative institutions throughout Europe in the Middle Ages was important to support commercial development; and finally that there was a link between the education of individuals in law and the development of favorable legal institutions.

\subsection{Universities and Legal Training}

Although not all university students studied the law (as noted above, universities also provided training in the arts, in theology, and in medicine), a large fraction did. It is difficult to obtain precise estimates of the number of students graduating with a law degree from any university, before or after the Schism. However, one can look at matriculation records and count the number of students enrolled at a certain university at one point in time. ${ }^{40}$

If we consider the number of matriculated students, the following picture emerges. In 1389, one year after its foundation, the university of Cologne had 759 matriculated students, of whom 156 (20.5 percent) were studying law. According to estimates, 15 percent of German university

\footnotetext{
${ }^{40}$ Note that counting graduates (rather than students) of universities would be problematic: many students who were enrolled did not ultimately graduate, as graduation was a costly procedure, involving the purchase of new gowns for all professors and the organization of a rich banquet. However, even students who had only attended a university for some years without achieving the doctorate degree certainly acquired human capital and were employed in positions where their education was put to use (Wieacker, 1967, p. 159).
} 
students in the second half of the fifteenth century were enrolled in law, or about 1,000 students in any given year (García y García, 1992, p. 400). ${ }^{41}$ This was a substantial increase compared to the number of German students enrolled in foreign universities before the Schism.

To put these figures in context, note that for the case of the university of Bologna it is known that 489 German students were enrolled there (across all disciplines) over the course of the entire 13th century, and 1650 students in the 14th century (Coing, 1964, p. 48). Assuming, rather conservatively, that foreign students spent, on average, eight years at a university, this would imply that during the 14th century there were about 125 German students enrolled in Bologna at any point in time. Bologna had the largest contingent of German students abroad, so it is likely that the total number of German students enrolled in foreign universities was never close to the 1,000 students enrolled just in law in the German universities of the late fifteenth century. It seems safe to say, therefore, that the establishment of the universities as a consequence of the Schism substantially increased-perhaps by an order of magnitude - the number of individuals in the German lands trained in the law.

\subsection{The Establishment and the Importance of a System of Laws for Economic Activity}

The time of the Commercial Revolution was also the time of the reestablishment of Roman law in Europe. ${ }^{42}$ The Justinian Code, "rediscovered" in the eleventh century, provided the foundation for a legal system that could enforce contracts and define the relationship between the rulers and the ruled. The Code became the core curriculum at Europe's first university, in Bologna, and over the centuries it formed the basis of the civil law curriculum in universities throughout Europe. Doctors of law at the universities wrote glosses on (interpretations of) the Code and lectured on these; as their students spread throughout Europe, the legal system in which they were trained spread, too.

Roman law represented a significant improvement over the pre-existing systems of customary

\footnotetext{
${ }^{41}$ Coing (1964, p. 66) reports some attempts to estimate the actual number of graduating students: over the entire period 1386-1540, more than 1,800 students graduated in law from German universities, the largest shares of which graduated from Leipzig (504 graduates), Erfurt (427), Cologne (388), and Heidelberg (219).

${ }^{42}$ We join legal scholars in attaching preeminent importance to the rediscovery of the Justinian code, as opposed to other codifications of that epoch, such as the Sachsenspiegel.
} 
law. Whereas customary law was very local, Roman law was universally known across Europe; whereas customary law was highly traditional, based on kinship and superstition, Roman law was an authoritative yet flexible system, that had been enriched by centuries of scholarship; whereas traditional law was informal and feuds were often preferred to trial, Roman law was writtencontributing to the increasing importance of written evidence in the Middle Ages ${ }^{43}$-and based on a process of rational pursuit of truth (Berman, 1983). In the particular context of Germany, with its highly fractionalized territories, these advantages of Roman law were particularly salient. ${ }^{44}$ Broadly-applied, rule-based, written laws effectively reduced the uncertainty faced in economic transactions.

Though our primary focus is on Roman law, the importance of canon law in all spheres of public life in medieval times should not be neglected. In particular, the Church's competence in cases which would today be regarded as purely belonging to secular law was substantial. ${ }^{45}$ Because contracts relied on promises and sworn oaths, the Church played a role in contract enforcement, even when the parties to the contract were not clerics. As pointed out by Berman (1983, p. 250), "the canonists were able, with the help of Romanist legal science, to create a subsystem of contract law within the system of canon law as a whole." In fact, most students enrolled in medieval universities would study both canon and Roman law-utrumque ius (both laws), as it was commonly expressed. Moreover, cases were often brought to the attention of ecclesiastical tribunals even if they did not strictly belong to their field of competence because of their perceived independence and better ability to enforce sanctions (Kroeschell, 1973, p. 23).

The increasing application of Roman and canon law across all spheres of public life could have had a series of positive effects on economic development. The broadest argument along these lines has been put forward by the legal historian Harold Berman, who suggested that the

\footnotetext{
${ }^{43}$ See Mostert, ed (1992) on this process, known as Verschriftlichung/verschriftelijking. On the written component of canon law, see Coing (1964, p. 79), and on the increasing use of written records in city and maritime courts, see Berman (1983, p. 355).

${ }^{44}$ Wieacker (1967, pp. 105, 112). See also Stobbe (1860, p. 637) and Savigny (1834, vol. 3, p. 84).

${ }^{45}$ The Church's tribunals dealt with causae saeculares in the following cases: ratione peccati, i.e., cases in which the subject matter was considered a sin and hence had to be confessed to a priest; privilegium fori, i.e., the participation of a cleric as a plaintiff or defendant, or other special categories, such as Jews and sometimes even university students; and denuntiatio evangelica, i.e., the evident necessity to apply moral or theological reasoning (Wieacker, 1967, p. 76).
} 
rediscovery of Roman law, and the increasing development and sophistication of European legal systems (canon, Roman, and merchant law), brought a new approach to the solution of conflicts between secular and religious authorities which had plagued Europe during the better part of the Middle Ages (Berman, 1983, pp. 160-162). This helped resolve disputes that existed between various jurisdictions, distinguish between conflicting legal claims within the various secular polities, and ultimately served to support and stabilize the process of state formation. Stronger states, in which multiple layers of sovereignty were simplified and overlapping entitlements solved, found it easier to organize economic activity and establish markets.

This channel of influence of Roman and canon law on economic development is reflected in the career choices increasingly pursued by legal scholars. Moraw (1992, p. 273) writes that in the late Middle Ages, “[a]s far as most modern [legal] careers are concerned, leadership passed to the secular authorities. ... [T] $]$ here was something like a legal, secular, administrative and judicial 'career path' which it was possible to choose on the basis of appropriate study." García y García (1992) provides a similar description of law graduates' careers: "[L]aw graduates, both clerics and laymen, held official posts with various authorities, from the imperial and royal chanceries downwards. Both in the church and in civilian employment men of law held economic as well as administrative posts."

Second, law could have served as a coordination device (Postema, 1982; McAdams, 2000). This was true even in the absence of effective sanctions by a governmental authority: especially when states were weak, the recourse to a shared set of legal concepts, as represented by Roman and canon law, facilitated the interaction between parties. Fixed typologies of contracts, or provisions determining the default rules in the absence of explicit provisions, may have served as focal points. Referring to the older Roman law, Berman (1983, p. 245) writes, "[it] had achieved a very high level of sophistication in the field of contracts, and much of its vocabulary in that field, as well as many of its solutions to individual questions, could be applied in the twelfth century to the newly burgeoning commercial life in Western Europe." This legal toolkit would have been even easier to apply as it spread and gained acceptance in the thirteenth and fourteenth centuries. Vinogradoff (1929, p. 138, 143-144) writes that in the Middle Ages "it became more and more usual for parties 
to a suit to submit the points in dispute to the arbitration of doctors of law," and that the influence of Roman law was "especially manifest in the law of contracts."

Finally, the spread of Roman legal thinking could have supported market exchange by making adjudication more predictable. If judges were increasingly trained following a common curriculum of studies, and were thus expected to follow those principles when passing judgments, contracting would have been made easier in the expectation of more certain procedures of adjudication. Greater access to information about these rules may have been important, too: judges relying on written law were more predictable than judges relying on unwritten principles.

For all of these reasons-more clearly defined state institutions and jurisdictions, greater simplicity of writing of contracts, and more predictable adjudication-a better-developed formal legal system should have increased commercial exchange, and provided stronger incentives for the creation of new urban centers and markets.

\subsection{Jurists and Their Employment in the German Lands}

The development of Europe's and Germany's formal legal institutions alongside the foundation of the first universities was not coincidental. Empirical evidence supports the hypothesis that the channels put forward in the previous discussion-linking universities and the development of Roman and civil law to the creation of an administrative class that provided a supportive institutional environment for commercial exchange-were at work in late medieval Germany.

As a first step, we consider the role universities played in manning Germany's secular and Church administrations, examining the careers of university students after they left school. Kuhn (1971) collected information on 1,627 students from Tübingen University from the years 1477 to 1534. Around 20 percent of students in Kuhn's sample served in public administration jobs (see Table 7) - a surprisingly high number given that many of these students did not study law, but the arts or theology. In addition, this percentage may understate university students' impact on administration to the extent many members of the clergy were active for the Church in administrative positions-many territorial lords in the Empire were bishops with temporal powers-or in Church tribunals. In the sub-sample of students who attended both Tübingen and Bologna 
(69 students) — these were overwhelmingly students of law-an even larger fraction of students, around 30 percent, pursued public administration careers (Table 7, Panel B), and again, others may have been administrators within the Church. We also consider the careers of 1,212 law graduates from the University of Bologna (of all nationalities), from 1070 through 1619, as recorded by Alidosi (1623). We find that 21 percent of the graduates pursued careers in public administration, and another 31 percent pursued non-clergy administrative careers in the Church (see Table 7, Panel C).

[Table 7 about here]

It remains to be shown that secular and Church administrators trained in the law in fact worked to develop formal legal institutions. While formal adoption of Roman law in the Holy Roman Empire did not occur until the late 15th century, some of its characteristic elements entered the political, judicial and commercial spheres earlier than that, thanks to the large number of legally trained individuals; this process is known as Frührezeption (early reception). ${ }^{46}$ Law graduates influenced this development by taking up administrative positions in the Church and in secular territories, and by their activity in the judicial systems of Church, cities, states, and Empire. Those who were not able to complete their university degree could also find employment in positions of relative economic importance, working as chroniclers, notaries or procurators, and representing cities in official political and commercial transactions. ${ }^{47}$

The rise of territorial states within the Empire was a fundamental factor favoring the reception of Roman law. In the particular case of Germany, the legal standing of cities and territories rested upon a myriad of privileges, grants, contracts and other legal acts: importantly, city incorporation grants and market rights were among those. Jurists were therefore needed to formulate those documents and enforce the states' rights vis-à-vis other polities, and in their activities as

\footnotetext{
${ }^{46}$ See Trusen (1962), Coing (1964), Wieacker (1967). It is interesting to observe that in nearby Austria, where Roman law was not taught, it did not enter the public sphere either. The university of Vienna taught only Canon law during the whole 15th century; as a consequence, the use of Roman law in the administration of the Austrian territories diffused only much later, in the 16th and 17th centuries (Baltl, 1962, pp. 64-70).

${ }^{47}$ Wieacker (1967, p. 159). Vinogradoff (1929, p 133) writes that "the persons who had recourse to Roman texts ... [were] town-clerks acting as jureconsults to cities and to princes, and taking part in the discussions of ordinary tribunals as assessors." On jurists serving cities and territories in Germany, and influencing their jurisdiction as well as their economic policy, see also Dotzauer (1977) and Nicholas (1977, pp. 156-159).
} 
legal counselors and advisers to princes and city governments jurists acted as both lawyers and diplomats (Wieacker, 1967, pp. 101-112; Coing, 1964, §26).

In fact, one of the first activities of jurists working for the secular and ecclesiastic administrations of the Empire was as arbitrators, adjudicating disputes between cities, territories, and the Church. The demand for experts trained in Roman law to solve these cases existed even before the creation of universities in Germany. For example, a dispute between the Dukes of Bavaria and the Archbishops of Salzburg was resolved with the advice of experts from Padua in 1283; in 1300, Italian scholars were asked to solve some dubious points in the foundation charter of the city of Elbing (Stobbe, 1860, p. 629). It is safe to assume that the presence of locally-trained jurists made the recourse to Roman law to adjudicate disputes between powers easier and more frequent. ${ }^{48}$

Within the Church, jurists found employment as counsellors and administrators in the service of bishops and clergymen with temporal powers (such as prince-bishops), as well as in ecclesiastical tribunals (Offizialatsgerichte). There, they were active as judges or procurators (solicitors) of one of the parties. The requirement of written records in all proceedings of ecclesiastical tribunals made a large number of chroniclers necessary; these were often trained in the law and could later become judges themselves (Kroeschell, 1973, p. 22). The Church was also very active in the authentication of documents: for example, around the middle of the 15th century the ecclesiastical tribunal of Strasbourg was authenticating about 300-600 documents per week (Coing, 1964, §25; Trusen, 1962, p. 66).

Over the course of the 15th century, individuals trained in the law working for secular territories were not only employed in arbitration cases, but also in regular courts. Roman law became a legitimate source of legal thinking; this was reflected in the judgments of court councilorsincreasingly trained at universities - who gave rulings on behalf of the local territorial lords. The adoption of Roman law culminated in the creation of special courts, such as the one in Leipzig (founded 1432), which was composed of faculty members of the local university, and supreme courts of the states of the Empire (Palatinate 1472, Saxony 1483, Württemberg 1495), which adjudicated according to Roman law (Wieacker, 1967, pp. 177-180). The central administration of the

\footnotetext{
${ }^{48}$ See, in particular, Muther (1864, p. 424) and Trusen (1962, p. 218).
} 
Holy Roman Empire was also a substantial employer of university graduates trained in the law: between 1273 and 1493, at least 230 jurists served in the Imperial Court. Most of these served in the century following the establishment of the first universities in Germany, both in an administrative capacity and in a judicial court, the Reichskammergericht (Moraw, 1986, p. 143).

Several exemplary careers of jurists trained in Roman law rising to important positions in Church and governments, and working to create an institutional environment favorable to economic development, can be found. Winand von Steeg studied and graduated from the University of Heidelberg from 1394 until 1401. After having taught law in Würzburg and worked as a canon, he finally served as an envoy of the city of Nuremberg to the Council of Constance (1414-1418). Later on, he arbitrated a dispute about custom payments for transit shipments on the Rhine, and was asked to deliver an expert testimony on the legality of the purchase of rents. The career of Albert Varrentrapp is comparable: after having studied and taught law at the University of Cologne, he was later an envoy in Constance and Basle, worked as a notary and judge, and finally as curator of the Cathedral in Liege. ${ }^{49}$ Muther (1876, pp. 26-29) cites the case of Arnold Westphal: he taught law in Erfurt, Leipzig, and Rostock, was nominated bishop of Lübeck, wrote legal treatises, was asked for his legal advice by the rulers of Schleswig-Holstein and Denmark, and arbitrated in Prussia. While these career paths are clearly outstanding, they are indicative of the variety of activities that trained jurists of the 14th and 15th century could have engaged in.

In addition to employment in the administration of Church and secular governments, it should be noted that the influence of jurists on the establishment of markets may have been more direct. For the duration of a market, merchants normally assembled a court composed of their peers, but professional jurists were increasingly part of such committees; the same was true for private lay courts (Schöffenstühle) and arbitration courts (Schiedsgerichte), where legally trained individuals could be active as arbitrators, assessors, or procurators (Berman, 1983, p. 346; Wieacker, 1967, pp. 179-180; Coing, 1964, p. 90). Public notaries, who helped to secure property rights and were often linked to the Church, were yet another vehicle through which Roman legal concepts entered the public sphere in Germany (Wieacker, 1967, p. 117).

\footnotetext{
${ }^{49}$ These careers are drawn from the Repertorium Academicum Germanicum, http://www.rag-online.org/, a database collecting the biographies of scholars of the Holy Roman Empire from 1250 until 1550.
} 
University training in the law was thus closely linked to occupations that were likely to affect commercial activity in medieval Germany. The establishment of a legal system improved the public bureaucracy as well as supported the writing and enforcement of private contracts; these consequences plausibly supported commercial expansion, namely the rise of markets and fairs.

\section{Conclusion}

Understanding the "Rise of the West" is a monumental task, made more difficult by the fragmentary data available for the late medieval period when it began. To begin to study the economic aspects of the transformation of Europe requires systematic evidence on economic activity. Our evidence on medieval German city incorporation and market establishment indicates remarkable changes in economic activity: hundreds of markets were established during the Commercial Revolution in Germany.

These data allow us to test whether medieval universities played a causal role in the increased economic activity we observe. Medieval Germany experienced a plausibly exogenous shock to its human capital stock through the universities established there during the Papal Schism. Following the universities' foundation, trend rates of market establishment sharply increased. The break in trend was largest in areas that saw the greatest decrease in distance to a university during the Papal Schism, and did not occur in cities that were no closer to a university at the end of the Schism than at the beginning. These results do not seem to have been driven by the endogenous choice of where universities were established, nor by some other effect of the Papal Schism. The evidence presented suggests an important, causal role for universities in the development of markets in medieval and early modern Germany.

While identifying the channel linking universities' proximity to market establishment is difficult, historical evidence indicates the importance of legal training provided by medieval universities. The number of German law students dramatically increased following the establishment of the first universities there; many of them then went on to administrative careers in which they helped develop new legal institutions, thus reducing the uncertainty of engaging in trade. We 
suggest that the development of formal and legal institutions thus played a key role in promoting economic transformation.

The "natural experiment" in university establishment that we analyze occurred well into the late Middle Ages, and outside the most commercially successful parts of medieval Europe. Still, we think that the experience of Germany in the late fourteenth and early fifteenth century not only provides an ideal testing ground due to the exogenous introduction of universities, but we also believe that these insights reveal the importance of universities and (and legal institutions' development) throughout Europe in the Middle Ages. The channel from universities to legal training, to careers in public administration and Church administration was clearly exhibited among the University of Bologna's medieval graduates, who came from across Europe. With regard to France, Swanson (1979, p. 15) writes that "universities became the training schools for the bureaucrats of both secular and ecclesiastical chanceries; ... from the beginning of the thirteenth century the law graduates of the French provincial universities dominated the personnel of the French chancery." These public administrators (including those within the Church) helped to establish the political institutions that Berman (1983), Epstein (2000), and De Long and Shleifer (1993) argue were crucial to Europe's medieval economic growth. ${ }^{50}$

Other research questions regarding the Commercial Revolution remain open: the establishment of universities and consequent development of legal institutions were certainly not alone in driving economic change. Deeper analysis of the patterns of city incorporation and market establishment may yield new insights about other important causal factors. In addition, understanding the links, if any, between medieval economic change and the economic changes of the modern era would be valuable.

\footnotetext{
${ }^{50}$ The ability of the state to employ better-trained bureaucrats is an important determinant of a state's capacity (Brewer, 1988; Besley and Persson, 2009).
} 


\section{Appendix: Derivation of the Estimation Equation}

Here we provide details on the derivation of our estimating equation for our panel dataset. Using the definition given in equation (2) of section 3.3, we can write each city's level of human capital at a point in time as a function of its pre-Schism level of human capital, $h_{i, 1386}$, the postuniversity dummy, Post $t_{\text {, }}$ each city's change in distance to a university following the Papal Schism, $\Delta$ Dist Univ $_{i}$, and the coefficients $\delta_{t-j}$. To see this, note that for $t \leq 1386$ :

$$
h_{i, t}=-\sum_{j=1}^{n} \beta_{t-j} \cdot \text { distance }_{i, t-j}=- \text { distance }_{i, p r e} \cdot \sum_{j=1}^{n} \beta_{t-j} \equiv h_{i, 1386}
$$

In 1387 (and analogously, for the years after 1387), the level of human capital in cities with positive values of $\Delta$ Dist Univ $_{i}$ can be written as:

$$
\begin{aligned}
h_{i, 1387} & =-\beta_{t-1} \cdot \text { distance }_{i, 1386}-\beta_{t-2} \cdot \text { distance }_{i, 1385}-\beta_{t-3} \cdot \text { distance }_{i, 1384}-\ldots \\
& =-\beta_{t-1} \cdot\left(\text { distance }_{i, p r e}-\Delta \text { DistUniv }_{i}\right)-\beta_{t-2} \cdot \text { distance }_{i, p r e}-\beta_{t-3} \cdot \text { distance }_{i, p r e}-\ldots \\
& =h_{i, 1386}+\beta_{t-1} \cdot \Delta \text { DistUniv }_{i}
\end{aligned}
$$

Thus, prior to 1387, human capital in our model will be approximately flat at the level $h_{i, 1386}$; for 1387 and the following years, human capital is equal to:

$$
h_{i, t}=h_{i, 1386}+\text { Post }_{t} \cdot \Delta \text { DistUniv }_{i} \cdot \sum_{j=1}^{t-1386} \delta_{t-j}
$$

To simplify, we approximate the unknown series of $\delta_{t-j}$ with a time trend and plug this back into equation (1). This yields, after redefining coefficients:

$$
\begin{aligned}
\text { markets }_{i, t} & =\alpha_{1} \cdot \text { Year }_{t}+\gamma\left(h_{i, 1386}+\Delta \text { DistUniv }_{i} \cdot \text { Year }_{t} \cdot \text { Post }_{t}\right) \\
& \equiv \bar{h}_{i, 1386}+\alpha_{1} \cdot \text { Year }_{t}+\alpha_{7} \cdot \Delta \text { DistUniv }_{i} \cdot \text { Year }_{t} \cdot \text { Post }_{t}
\end{aligned}
$$

where the variable Year $t_{t}$ is normalized to equal 0 in the pivot year.

Though not predicted by the model, reduction in distance to a university $\left(\Delta\right.$ Dist Univ $\left._{i}\right)$ and the Papal Schism ( Post $_{t}$ ) might both be associated with characteristics that directly affect market establishment in the level, in trends, or in their interactions. To account (and test) for these possible relationships, we include level and interaction effects of $\Delta$ Dist Univ $_{i}$ and Post $_{t}$. This yields the following equation:

$$
\begin{aligned}
& \text { markets }_{i, t}=\bar{h}_{i, 1386}+\alpha_{1} \cdot \text { Year }_{t}+\alpha_{2} \cdot \text { Post }_{t}+\alpha_{3} \cdot \text { Year }_{t} \cdot \text { Post }_{t}+\alpha_{4} \cdot \Delta \text { DistUniv }_{i} \\
& +\alpha_{5} \cdot \Delta \text { DistUniv }_{i} \cdot \text { Year }_{t}+\alpha_{6} \cdot \Delta \text { DistUniv }_{i} \cdot \text { Post }_{t} \\
& +\alpha_{7} \cdot \Delta \text { DistUniv }_{i} \cdot \text { Year }_{t} \cdot \text { Post }_{t}
\end{aligned}
$$

The city-specific intercepts $\bar{h}_{i, 1386}$ can be accounted for with city fixed effects. However, because the coefficients on the interaction terms of interest are invariant to the inclusion of city fixed effects, 
we do not include the fixed effects in our regressions. We therefore use the following estimation equation throughout:

$$
\begin{aligned}
& \text { markets }_{i, t}=\alpha_{0}+\alpha_{1} \cdot \text { Year }_{t}+\alpha_{2} \cdot \text { Post }_{t}+\alpha_{3} \cdot \text { Year }_{t} \cdot \text { Post }_{t}+\alpha_{4} \cdot \Delta \text { DistUniv }_{i} \\
& +\alpha_{5} \cdot \Delta \text { DistUniv }_{i} \cdot \text { Year }_{t}+\alpha_{6} \cdot \Delta \text { DistUniv }_{i} \cdot \text { Post }_{t} \\
& +\alpha_{7} \cdot \Delta \text { DistUniv }_{i} \cdot \text { Year }_{t} \cdot \text { Post }_{t}+\varepsilon_{i, t}
\end{aligned}
$$




\section{References}

Acemoglu, Daron, Davide Cantoni, Simon Johnson, and James A. Robinson, "The Consequences of Radical Reform: The French Revolution," American Economic Review, December 2011, 101 (7), 3286-3307.

-, Simon Johnson, and James Robinson, "The Rise of Europe: Atlantic Trade, Institutional Change, and Economic Growth," American Economic Review, June 2005, 95 (3), 547-579.

Alidosi, Giovanni, Li dottori bolognesi di legge canonica e civile dal principio di essi per tutto l'anno 1619, Bologna: Per Nicolò Tebaldini, 1623.

Bairoch, Paul, Jean Batou, and Pierre Chèvre, La population des villes européennes, 800-1850: Banque de données et analyse sommaire des résultats, Geneva: Droz, 1988.

Baltl, Herrmann, "Einflüsse des römischen Rechts in Österreich," in "Ius Romanum Medii Aevi," Vol. 5:7, Milano: Giuffrè, 1962.

Berman, Harold, Law and Revolution: The Formation of the Western Legal Tradition, Cambridge, Mass.: Harvard University Press, 1983.

Besley, Timothy and Torsten Persson, "The Origins of State Capacity: Property Rights, Taxation, and Politics," American Economic Review, 2009, 99 (4), 1218-44.

Bosker, Maarten and Jan Luiten van Zanden, “From Baghdad to London: The Dynamics of Urban Growth in Europe and the Arab World, 800-1800," CEPR Discussion Paper, 2008, 6833.

Brenner, Robert, "Agrarian Class Structure and Economic Development in Pre-Industrial Europe," Past and Present, February 1976, 70, 30-75.

Brewer, John, The Sinews of Power, Cambridge, Mass.: Harvard University Press, 1988.

Britnell, Richard H., "English Markets and Royal Administration before 1200," Economic History Review, May 1978, 31 (2), 183-196.

_ , "The Proliferation of Markets in England, 1200-1349," Economic History Review, May 1981, 34 (2), 209-221.

Buringh, Eltjo and Jan Luiten van Zanden, "Charting the 'Rise of the West': Manuscripts and Printed Books in Europe, A Long-Term Perspective from the Sixth through Eighteenth Centuries," Journal of Economic History, 2009, 69 (2), 409-445.

Clark, Gregory, A Farewell to Alms; A Brief Economic History of the World, Princeton, N.J.: Princeton University Press, 2007.

Cobban, Alan B., The Medieval Universities: Their Development and Organization, Chatham: W. \& J. Mackay, Ltd. 1975.

Coing, Helmut, "Römisches Recht in Deutschland," in "Ius Romanum Medii Aevi," Vol. 5:6, Milano: Giuffrè, 1964. 
De Long, J. Bradford and Andrei Shleifer, "Princes and Merchants: European City Growth before the Industrial Revolution," Journal of Law and Economics, October 1993, 36 (2), 671-702.

DeRidder-Symoens, Hilde, ed., A History of the University in Europe: Universities in the Middle Ages, Vol. 3, Cambridge: Cambridge University Press, 1992.

Dittmar, Jeremiah, "Cities, Institutions, and Growth: The Emergence of Zipf's Law," March 2009. University of California, Berkeley.

Dotzauer, Winfried, "Deutsches Studium und deutsche Studenten an europäischen Hochschulen (Frankreich, Italien) und die nachfolgende Tätigkeit in Stadt, Kirche und Territorium in Deutschland," in Erich Maschke and Jürgen Sydow, eds., Stadt und Universität im Mittelalter und in der früheren Neuzeit, Sigmaringen: Thorbecke, 1977, pp. 112-141.

Epstein, Stephan R., An Island for Itself: Economic Development and Social Change in Late Medieval Sicily, Cambridge: Cambridge University Press, 1992.

_, Freedom and Growth: The Rise of States and Markets in Europe 1300-1750, London: Routledge, 2000.

García y García, Antonio, "The Faculties of Law," in Hilde DeRidder-Symoens, ed., A History of the University in Europe: Universities in the Middle Ages, Vol. 3, Cambridge: Cambridge University Press, 1992.

Greif, Avner, "Reputation and Coalitions in Medieval Trade: Evidence on the Maghribi Traders," Journal of Economic History, 1989, 49, 857-882.

- , "Contract Enforceability and Economic Institutions in Early Trade: The Maghribi Traders' Coalition," American Economic Review, June 1993, 83 (3), 525-548.

_ , "Cultural Beliefs and the Organization of Society: A Historical and Theoretical Reflection on Collectivist and Individualist Societies," Journal of Political Economy, 1994, 102 (5), 912-950.

_ , "The Fundamental Problem of Exchange: A Research Agenda in Historical Institutional Analysis," European Review of Economic History, 2000, 4, 251-284.

_ , Institutions and the Path to the Modern Economy, Cambridge: Cambridge University Press, 2006.

_ , Paul Milgrom, and Barry W. Weingast, "Coordination, Committment, and Enforcement: The Case of the Merchant Guild," Journal of Political Economy, August 1994, 102 (4), 745-766.

Grohmann, Alberto, Le fiere del Regno di Napoli in età aragonese, Napoli: Istituto italiano per gli studi storici, 1969.

Huff, Toby E., The Rise of Early Modern Science. Islam, China and the West, Cambridge: Cambridge University Press, 2003.

Keene, Derek and Samantha Letters, Markets and Fairs in England and Wales to 1516 [computer file], 2nd ed., Colchester, Essex: UK Data Archive [distributor], July 2004. SN: 4171, http://dx.doi.org/10.5255/UKDA-SN-4171-1. 
Keyser, Erich, Deutsches Städtebuch, Stuttgart: Kohlhammer, 5 vols., 1939-1974.

Kroeschell, Karl, Deutsche Rechtsgeschichte 2 (1250-1650), Hamburg: Rowohlt, 1973.

Kuhn, Werner, Die Studenten der Universität Tübingen zwischen 1477 und 1534; ihr Studium und ihre spätere Lebensstellung, Göppingen: Kuemmerle, 1971.

Lopez, Robert S., The Commercial Revolution of the Middle Ages, Cambridge: Cambridge University Press, 1976.

McAdams, Richard H., “A Focal Point Theory of Expressive Law," Virginia Law Review, 2000, 86 (8), 1649-1729.

McEvedy, Colin and Richard Jones, Atlas of World Population History, Harmondsworth and New York: Penguin, 1979.

Mira, Giuseppe, Le fiere lombarde nei secoli XIV-XVI; prime indagini, Como: Centro lariano per gli studi economici, 1955.

Mokyr, Joel, The Lever of Riches: Technological Creativity and Economic Progress, Oxford and New York: Oxford University Press, 1990.

Moraw, Peter, "Gelehrte Juristen in Dienst der deutschen Könige des späten Mittelalters (12731493)," in Roman Schnur, ed., Die Rolle der Juristen bei der Entstehung des modernen Staates, Berlin: Duncker und Humblot, 1986.

_ , "Careers of Graduates," in Hilde DeRidder-Symoens, ed., A History of the University in Europe: Universities in the Middle Ages, Vol. 3, Cambridge: Centro lariano per gli studi economici, 1992.

Morris, Ian, Why the West Rules... For Now, New York: Farrar, Straus and Giroux (forthcoming), 2010.

Mostert, Marco, ed., New Approaches to Medieval Communication, Turnhout: Brepols, 1992.

Murphy, Kevin M., Andrei Shleifer, and Robert W. Vishny, "The Allocation of Talent; Implications for Growth," Quarterly Journal of Economics, 1994, 106 (2), 503-530.

Muther, Theodor, "Zur Quellengeschichte des deutschen Rechts," Zeitschrift für Rechtsgeschichte, $1864,4,380-445$.

_ , "Römisches und canonisches Recht im deutschen Mittelalter," in Theodor Muther, ed., Zur Geschichte der Rechtswissenschaft und der Universitäten in Deutschland: Gesammelte Aufsätze, Jena: Dufft, 1876, chapter 1, pp. 1-37.

Nicholas, David, The Later Medieval City, 1300-1500, New York: Addison-Wesley, 1977.

North, Douglass C. and Robert P. Thomas, The Rise of the Western World: A New Economic History, Cambridge: Cambridge University Press, 1973.

Postema, Gerald J., "Coordination and Convention at the Foundations of Law," Journal of Legal Studies, 1982, 11 (1), 165-203. 
Rashdall, Hastings, The Universities of Europe in the Middle Ages, Oxford: Clarendon Press, 1895.

Savigny, Friedrich Karl von, Geschichte des römischen Rechts im Mittelalter, 2nd ed., Heidelberg: Mohr, 1834.

Schmieder, Felicitas, Die mittelalterliche Stadt, Darmstadt: Wissenschaftliche Buchgesellschaft, 2005.

Stobbe, Otto, Geschichte der deutschen Rechtsquellen, Vol. 1, Braunschweig: Schwetschke, 1860.

Swanson, Robert Norman, Universities, Academics, and the Great Schism, Cambridge: Cambridge University Press, 1979.

_ , "Universities, Graduates and Benefices in Later Medieval England," Past E Present, 1985, (106), $28-61$.

Trusen, Winfried, Anfänge des gelehrten Rechts in Deutschland; ein Beitrag zur Geschichte der Frührezeption, Wiesbaden: Steiner, 1962.

van Zanden, Jan Luiten, "Why the European Economy Expanded Rapidly in a Period of Political Fragmentation," in Jan Luiten van Zanden, ed., The Long Road to the Industrial Revolution: The European Economy in a Global Perspective, 1000-1800, Leiden: Brill, 2009, chapter 2, pp. 32-68.

Verger, Jacques, "Teachers," in Hilde DeRidder-Symoens, ed., A History of the University in Europe: Universities in the Middle Ages, Vol. 3, Cambridge: Cambridge University Press, 1992.

Verhulst, Adriaan, The Rise of Cities in North-West Europe, Cambridge: Cambridge University Press, 1999.

Vinogradoff, Paul, Roman Law in Medieval Europe, Oxford: Clarendon Press, 1929.

Wieacker, Franz, Privatrechtsgeschichte der Neuzeit. Unter besonderer Berücksichtigung der deutschen Entwicklung, 2nd ed., Vol. (English translation: A History of Private Law in Europe; With Particular Reference to Germany. Oxford: Oxford University Press, 1995.), Göttingen: Vandenhoeck \& Ruprecht, 1967. 
Figures and Tables

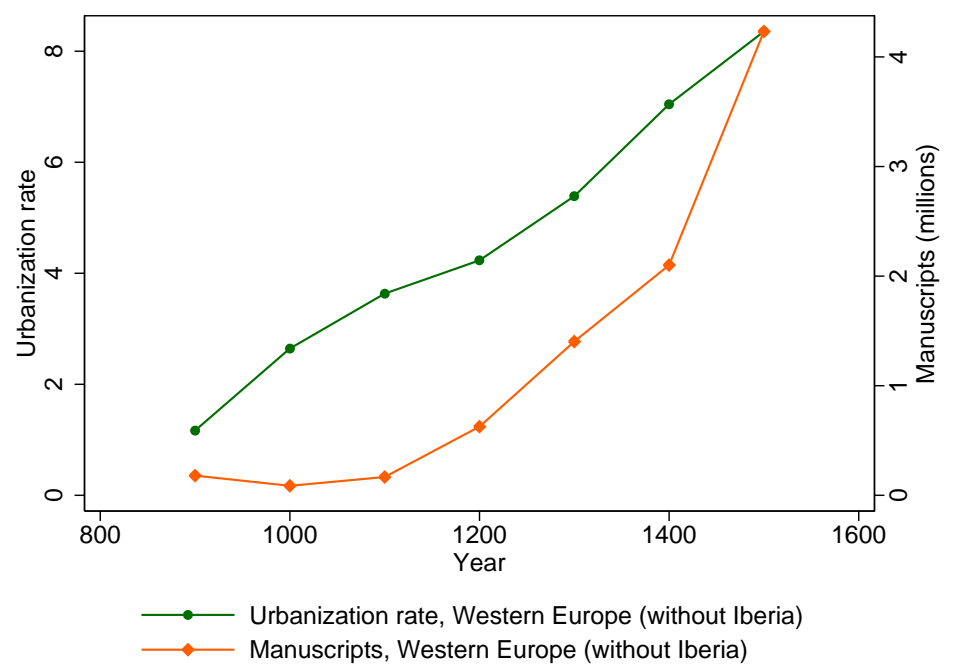

Figure 1: Indicators of economic development in the Middle Ages (source: Buringh and van Zanden, 2009)

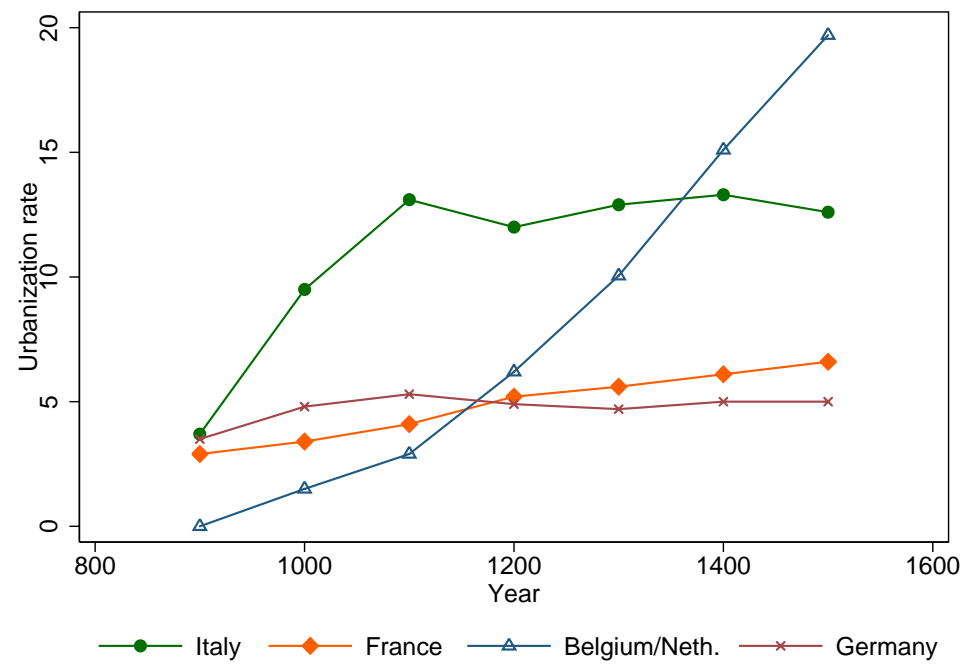

Figure 2: Urbanization rates (\% of the population living in cities with more than 10,000 inhabitants) in European regions (source: Buringh and van Zanden, 2009) 


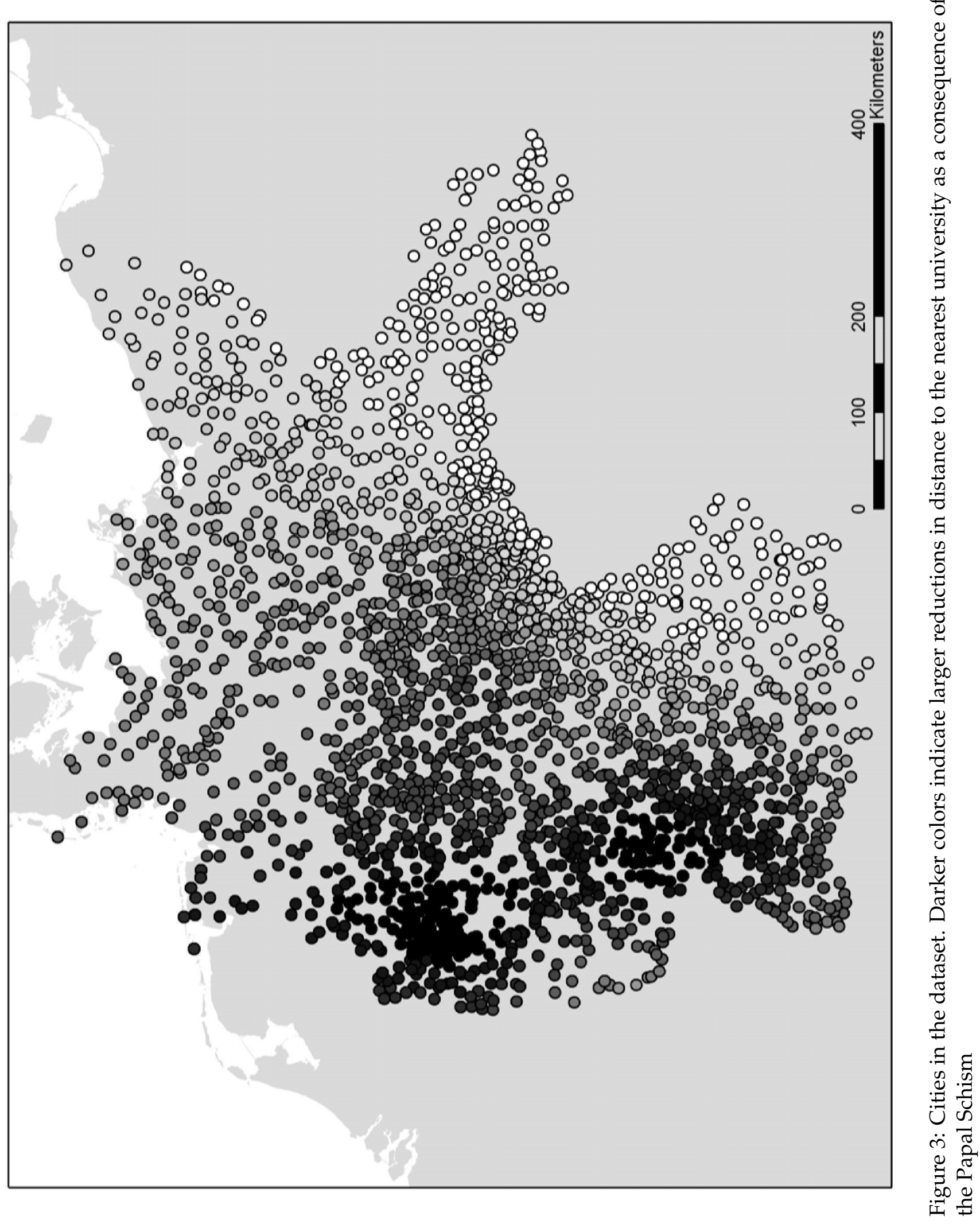




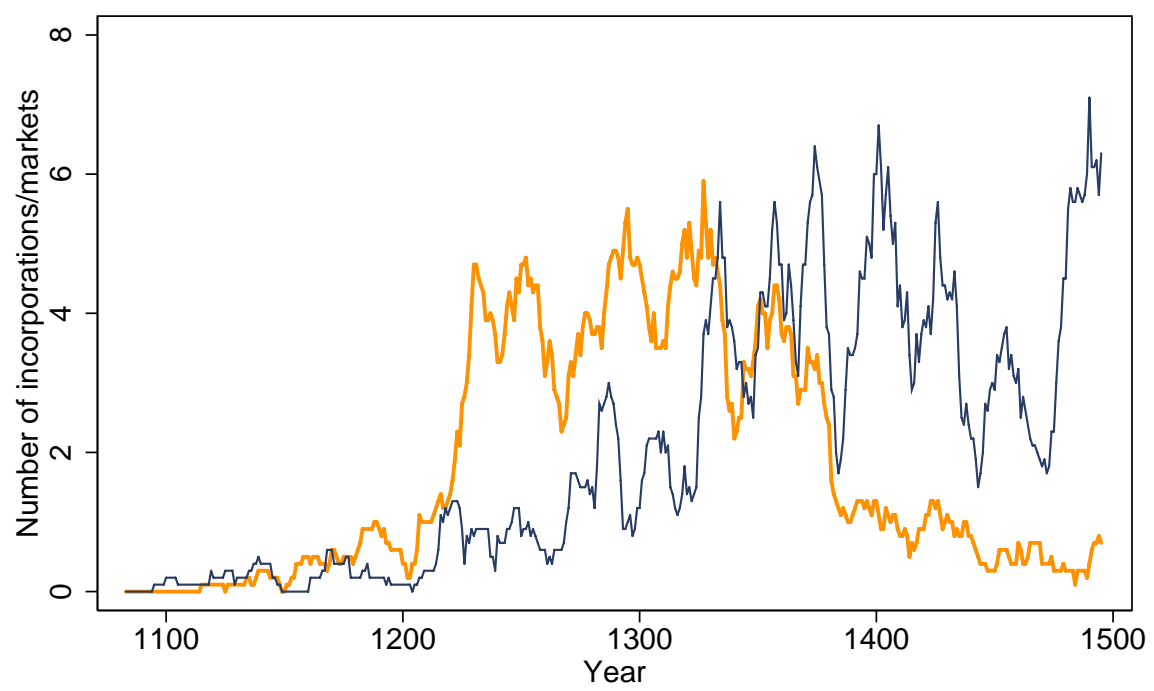

City incorporations (10 year moving average)

Market grants (10 year moving average)

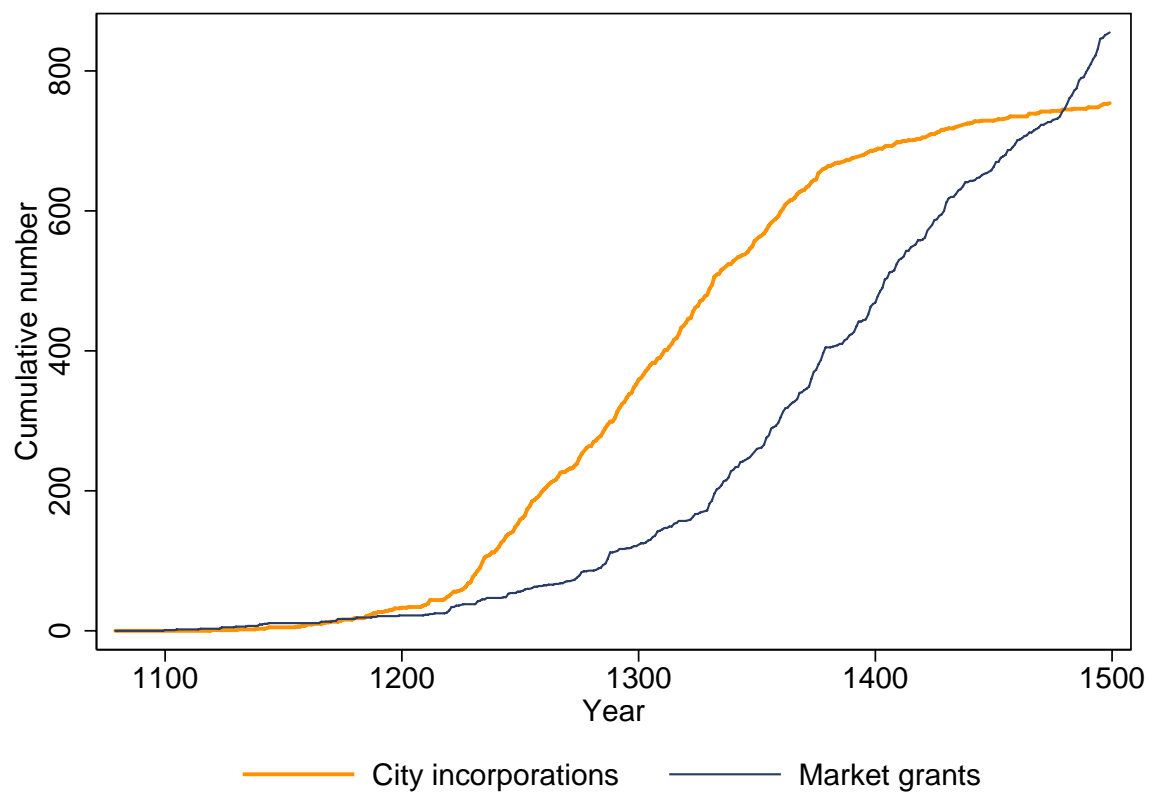

Figure 4: Absolute (10 year moving average) and cumulative number of city incorporations and market grants, Germany 


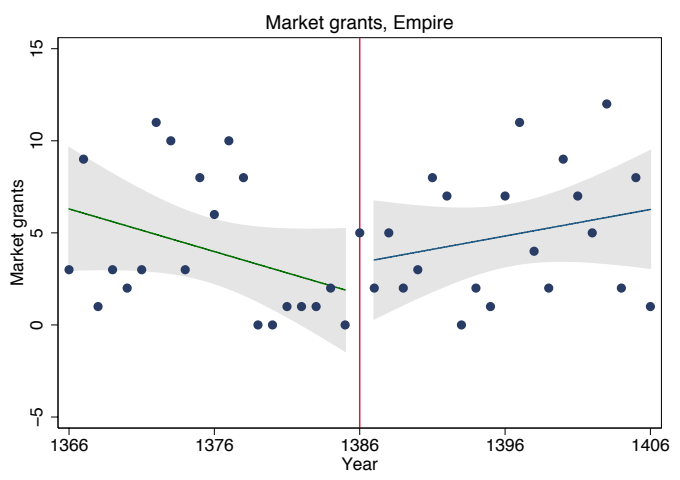

Figure 5: Changes in the trend rate of market establishment, whole sample (corresponding to the regression in Table 3, column 1)

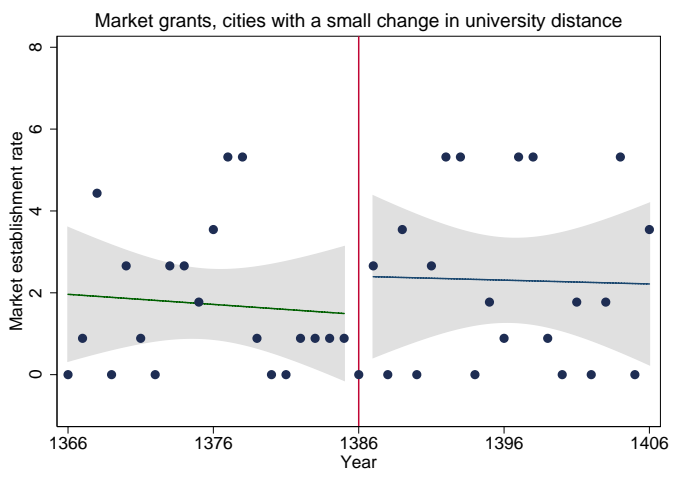

Figure 6: Changes in the trend rate of market establishment, cities with a small (below median) change in distance to the closest university (corresponding to the regression in Table 3, column 2)

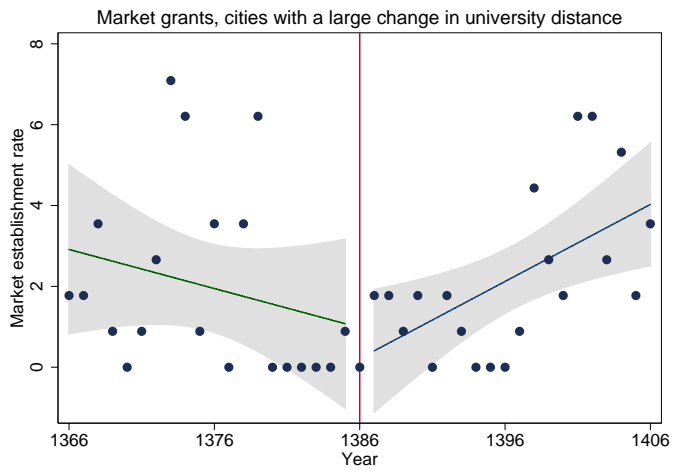

Figure 7: Changes in the trend rate of market establishment, cities with a large (above median) change in distance to the closest university (corresponding to the regression in Table 3, column 3) 


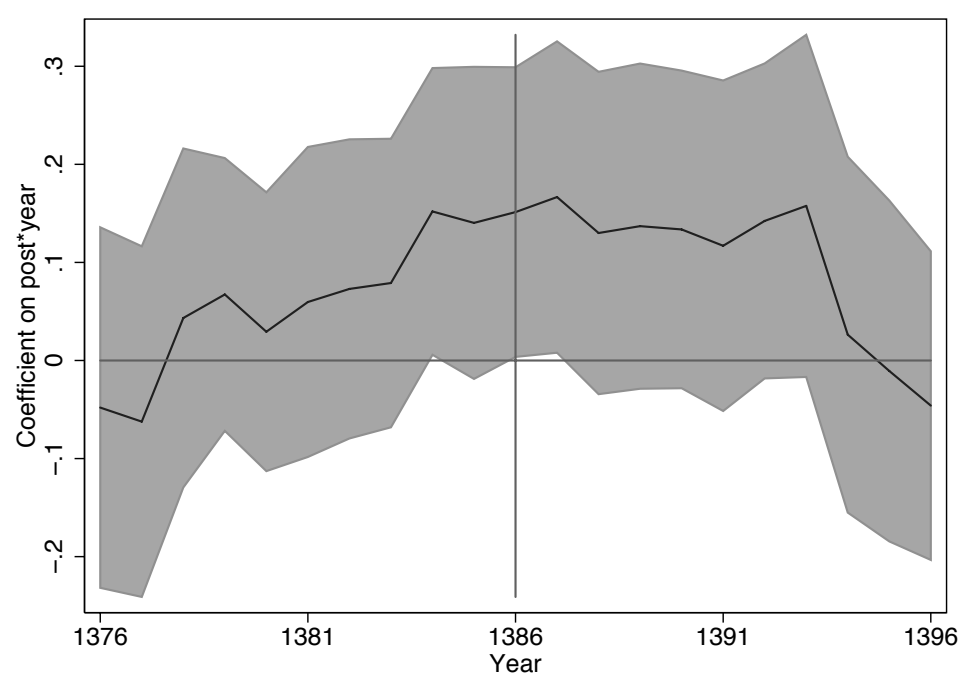

Figure 8: Changes in the trend rate of market establishment (coefficient on Year ${ }_{t} \cdot$ Post $_{t}$ ) under varying pivot years, 1376-1396

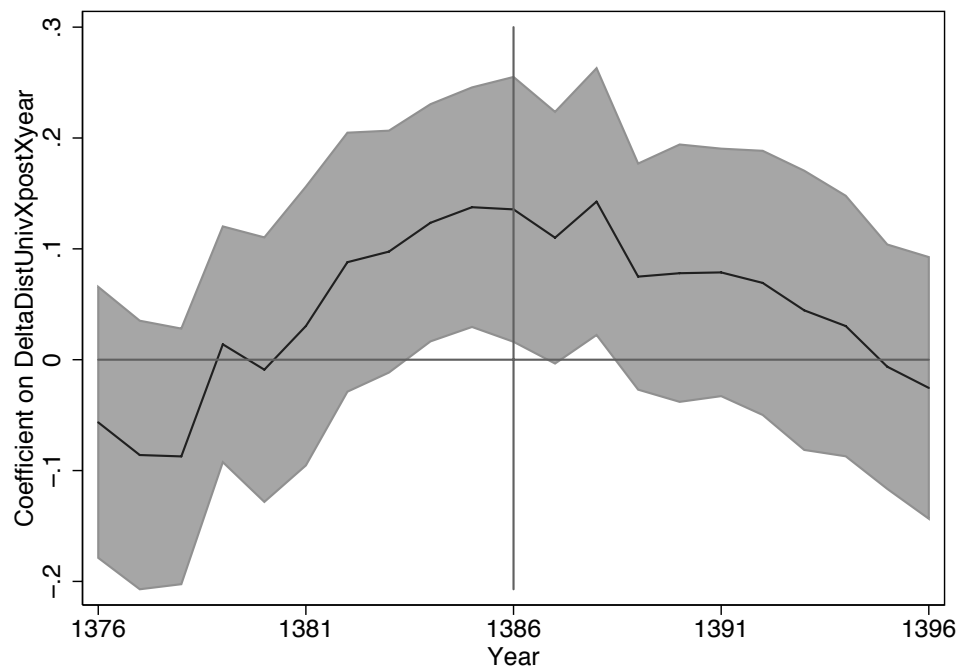

Figure 9: Changes in the trend rate of market establishment (coefficient on $\Delta$ DistUniv . Year ${ }_{t}$. Post $_{t}$ ) under varying pivot years, 1376-1396 
Table 1: University establishments

\begin{aligned} & \hline University Location Foundation Date \\ & \hline Bologna end of 12th Century \\ & Vicenza 1204 \\ & Paris beginning of 13th century \\ & Oxford beginning of 13th century \\ & Montpellier beginning of 13th century \\ & Cambridge $1209-1225 \\ &$ Arezzo 1215 \\ & Salamanca before 1218-1219 \\ & Padua 1222 \\ & Naples 1224 \\ & Vercelli 1228 \\ & Toulouse 1229 \\ & Orléans around 1235 \\ & Siena 1246 \\ & Angers 1250 \\ & Lisbon 1290 \\ & Lerida 1300 \\ & Avignon 1303 \\ & Rome 1303 \\ & Perugia 1308 \\ & Pisa 1343 \\ & Prague 1347 \\ & Florence 1349 \\ & Pavia 1361 \\ & Cracow 1364 \\ & Orange 1365 \\ & Vienna 1365 (opens in 1383) \\ & Erfurt 1379 (opens in 1392) \\ & Heidelberg 1386 \\ & Cologne 1388 \\ & Turin 1404 \\ & Leipzig 1409 \\ & St. Andrews 1411 \\ & Rostock 1419 \\ & Louvain 1425 \\ & Basle 1459 \\ & Tübingen 1476 \\ & \hline Sal \\ & \hline Sil \end{aligned}

Source: Verger (1992), pages 62-65. Universities in the territory considered by the dataset in italics. The foundation dates come from Verger (1992). Note that there is some ambiguity in the foundation dates of many of the early universities, so the numbers may differ slightly from those reported elsewhere. 
Table 2: Economic Shocks in Germany, 1200-1500

\begin{aligned} & \hline Date Event \\ & \hline 13th Century Creation of "commercial" schools that teach reading, arithmetic, bookkeeping \\ & Around 1250 Creation of the legal form of a corporation in Germany \\ & 1320 Discovery of gold in Hungary, decline of the Champagne fairs \\ & by 1345 Financial instruments such as IOU widely used \\ & 1348 First wave of the Black Death hits Europe \\ & 1439 Invention of printing with movable types by Johannes Gutenberg in Mainz \\ & $1470-1490$ Discovery of silver in Schwaz (Tyrol) and Schneeberg (Saxony) \\ & \hline Source: Cipolla (1976) and North (2000). \end{aligned}

Table 3: Baseline estimates

\begin{tabular}{|c|c|c|c|c|c|c|}
\hline \multirow{3}{*}{$\begin{array}{r}\text { Dependent variable: } \\
\text { Sample: }\end{array}$} & \multicolumn{6}{|c|}{ Rate of market establishment } \\
\hline & \multirow[b]{2}{*}{$(1)$} & $\begin{array}{l}<\text { median } \\
\Delta \text { DistUniv }\end{array}$ & $\begin{array}{l}\geq \text { median } \\
\Delta \text { DistUniv }\end{array}$ & $\begin{array}{c}\text { Panel, } \\
\text { city level }\end{array}$ & $\begin{array}{c}\text { Panel, } \\
\text { territory level }\end{array}$ & $\begin{array}{l}\text { Panel, } \\
\text { cell level }\end{array}$ \\
\hline & & (2) & (3) & $(4)$ & (5) & (6) \\
\hline \multirow[t]{2}{*}{ Year } & -0.061 & -0.025 & -0.097 & -0.004 & 0.087 & 0.018 \\
\hline & [0.053] & [0.059] & [0.061] & [0.075] & [0.126] & [0.051] \\
\hline \multirow[t]{2}{*}{ Post1386 } & 0.084 & 0.933 & -0.765 & 1.726 & -1.101 & 0.396 \\
\hline & [0.807] & [1.152] & [0.973] & [1.553] & [2.219] & [1.418] \\
\hline \multirow[t]{2}{*}{ Year $\times$ Post1386 } & $0.151^{* *}$ & 0.015 & $0.287^{* * *}$ & -0.086 & -0.129 & -0.068 \\
\hline & {$[0.073]$} & [0.097] & {$[0.084]$} & [0.138] & [0.205] & {$[0.094]$} \\
\hline \multirow[t]{2}{*}{$\Delta$ DistUniv } & & & & -0.173 & -0.808 & -0.364 \\
\hline & & & & [0.413] & [1.030] & [0.250] \\
\hline \multirow[t]{2}{*}{$\Delta$ DistUniv $\times$ Year } & & & & -0.032 & -0.058 & -0.030 \\
\hline & & & & [0.035] & [0.060] & {$[0.022]$} \\
\hline \multirow[t]{2}{*}{$\Delta$ DistUniv $\times$ Post1386 } & & & & -0.937 & 0.017 & -0.232 \\
\hline & & & & [0.630] & [1.069] & [0.593] \\
\hline \multirow[t]{2}{*}{$\Delta$ DistUniv $\times$ Year $\times$ Post1386 } & & & & $0.136^{* *}$ & $0.191^{*}$ & $0.094^{*}$ \\
\hline & & & & [0.059] & [0.108] & {$[0.049]$} \\
\hline \multirow[t]{2}{*}{ Constant } & $1.225^{*}$ & $1.470^{* *}$ & 0.980 & $1.529^{*}$ & 3.277 & $1.572^{* * *}$ \\
\hline & [0.615] & {$[0.684]$} & {$[0.784]$} & [0.829] & [2.307] & {$[0.564]$} \\
\hline Window (years) & \multicolumn{6}{|c|}{$1386 \pm 20$} \\
\hline Observations & 40 & 40 & 40 & 90240 & 20880 & 3200 \\
\hline Number of cities & 2256 & 1128 & 1128 & $\cdot$ & $\cdot$ & $\cdot$ \\
\hline Number of cross sectional units & $\cdot$ & · & · & 2256 & 522 & 80 \\
\hline
\end{tabular}




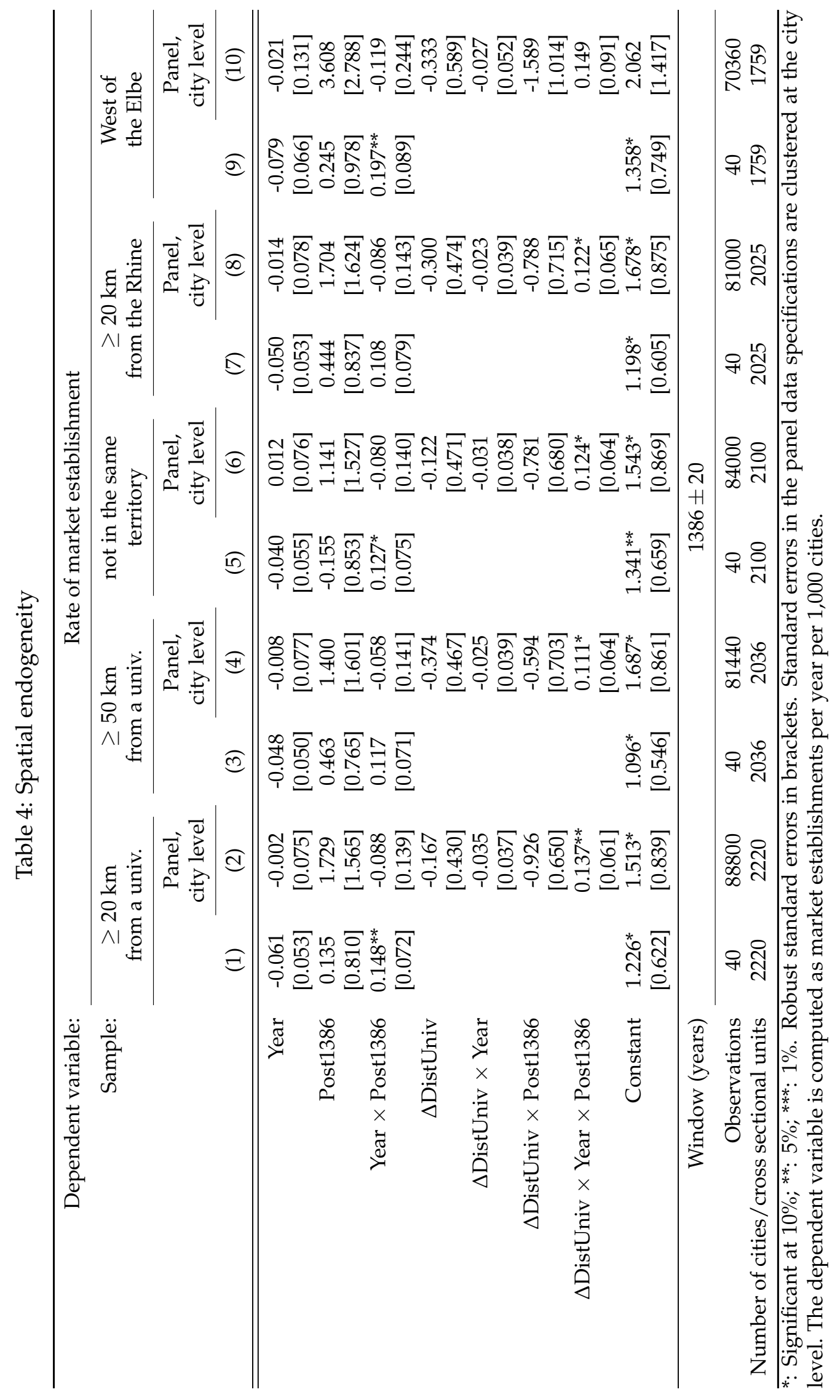




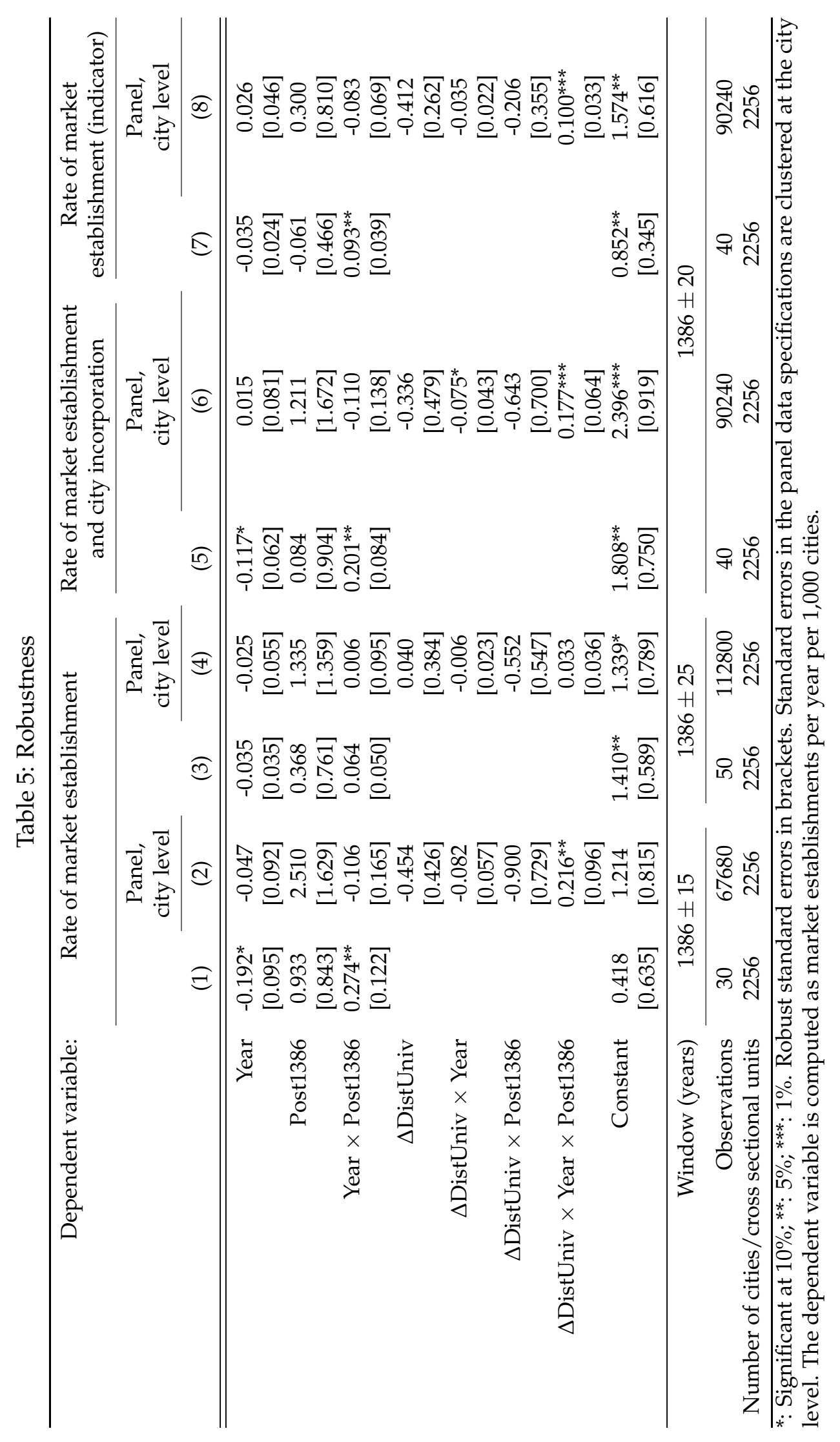


Table 6: Placebo analyses

\begin{tabular}{|c|c|c|}
\hline \multirow{3}{*}{$\begin{array}{r}\text { Dependent variable: } \\
\text { Sample: }\end{array}$} & \multicolumn{2}{|c|}{ Rate of market establishment } \\
\hline & Italy & $\begin{array}{l}\text { England } \\
\text { and Wales }\end{array}$ \\
\hline & (1) & (2) \\
\hline Year & $\begin{array}{c}0.115 \\
{[0.097]}\end{array}$ & $\begin{array}{c}0.110 \\
{[0.075]}\end{array}$ \\
\hline Post1386 & $\begin{array}{c}0.305 \\
{[2.581]}\end{array}$ & $\begin{array}{l}-2.034^{*} \\
{[1.177]}\end{array}$ \\
\hline Year $\times$ Post1386 & $\begin{array}{c}-0.008 \\
{[0.236]}\end{array}$ & $\begin{array}{c}-0.100 \\
{[0.089]}\end{array}$ \\
\hline Constant & $\begin{array}{l}2.521^{*} \\
{[1.257]}\end{array}$ & $\begin{array}{c}3.082^{* * * *} \\
{[1.014]}\end{array}$ \\
\hline Window (years) & \multicolumn{2}{|c|}{$1386 \pm 20$} \\
\hline Observations & 40 & 40 \\
\hline Number of cities & 190 & 2254 \\
\hline
\end{tabular}

Table 7: Careers of Graduates in Law

\begin{tabular}{lrr}
\hline Career & Abs. number & \% of sample \\
\hline Panel A: Tübingen graduates 1477-1534 & & \\
\hline Church (clergy) & 1095 & 67.3 \\
Academia & 133 & 8.17 \\
Public Administration & 327 & 20.1 \\
Other career & 72 & 4.43 \\
\hline Panel B: Tübingen and Bologna graduates 1477-1534 & & \\
\hline Church (clergy) & 21 & 30.43 \\
Academia & 8 & 11.59 \\
Public Administration & 21 & 30.43 \\
Other career & 19 & 27.54 \\
\hline Panel C: Bologna graduates 1070-1619 & \multicolumn{2}{c}{} \\
\hline Church (clergy) & 478 & 39.44 \\
Church Administration & 381 & 31.44 \\
Academia & 91 & 7.51 \\
Public Administration & 262 & 21.62 \\
\hline Source: Panels A-B, Kuhn (1971); Panel C, own tabulations based on Alidosi (1623).
\end{tabular}




\section{A Online Appendix}

\section{A.1 Region-specific trends}

In our model, we treated economic conditions that affected market establishment as following a linear trend common to all of Germany. In our empirical work, we examined the importance of reduced distance to a university exploiting variation in $\Delta$ DistUniv $_{i} \cdot$ Year $_{t} \cdot$ Post $_{t}$ from across Germany. However, one might believe that economic conditions followed different trends, and experienced different trend breaks in different regions of Germany around 1386. If so, and if those different trends and trend breaks were associated with $\Delta$ DistUniv $_{i}$, then this might affect our estimates of the coefficient on $\Delta$ Dist Univ $_{i} \cdot$ Year $_{t} \cdot$ Post $_{t}$.

Thus, we consider a specification that adds to our baseline specification state-specific time trends, as well as state-specific breaks of the trend in 1386 (that is, interaction terms of Yeart, Post $_{t}$, and Year $_{t} \cdot$ Post $_{t}$ with state dummies; we also include all of the lower-order interactions). We adopt the division of Germany into 18 states operated by the volumes of the Deutsches Städtebuch. ${ }^{51}$ This specification allows each state to follow its own pre-1386 trend rate of market establishment, and also allows each state to experience its own trend break in 1386 (as well as its own discrete "jump" in market establishment in 1386). In this setup, the effect of a change in university distance on market establishments is estimated only from the within-state variation of $\Delta$ Dist Univ $_{i}$.

As can be seen in Table A.1, our results from this specification are quite similar to our baseline. We continue to see a significant, positive coefficient on $\Delta$ Dist Univ $_{i} \cdot$ Yeat $_{t} \cdot$ Post $_{t}$.

\footnotetext{
${ }^{51}$ These are Bavaria, Baden, Württemberg, Hesse, Rhineland-Palatinate, Saarland, Rhineland, Westphalia, Lower Saxony (including Bremen), Schleswig-Holstein (including Hamburg), Saxony, Thuringia, Saxony-Anhalt, Brandenburg (including Berlin), Mecklenburg, Silesia, Pomerania (for the vast majority of cases, these states correspond to present-day Länder in the Federal Republic of Germany).
} 


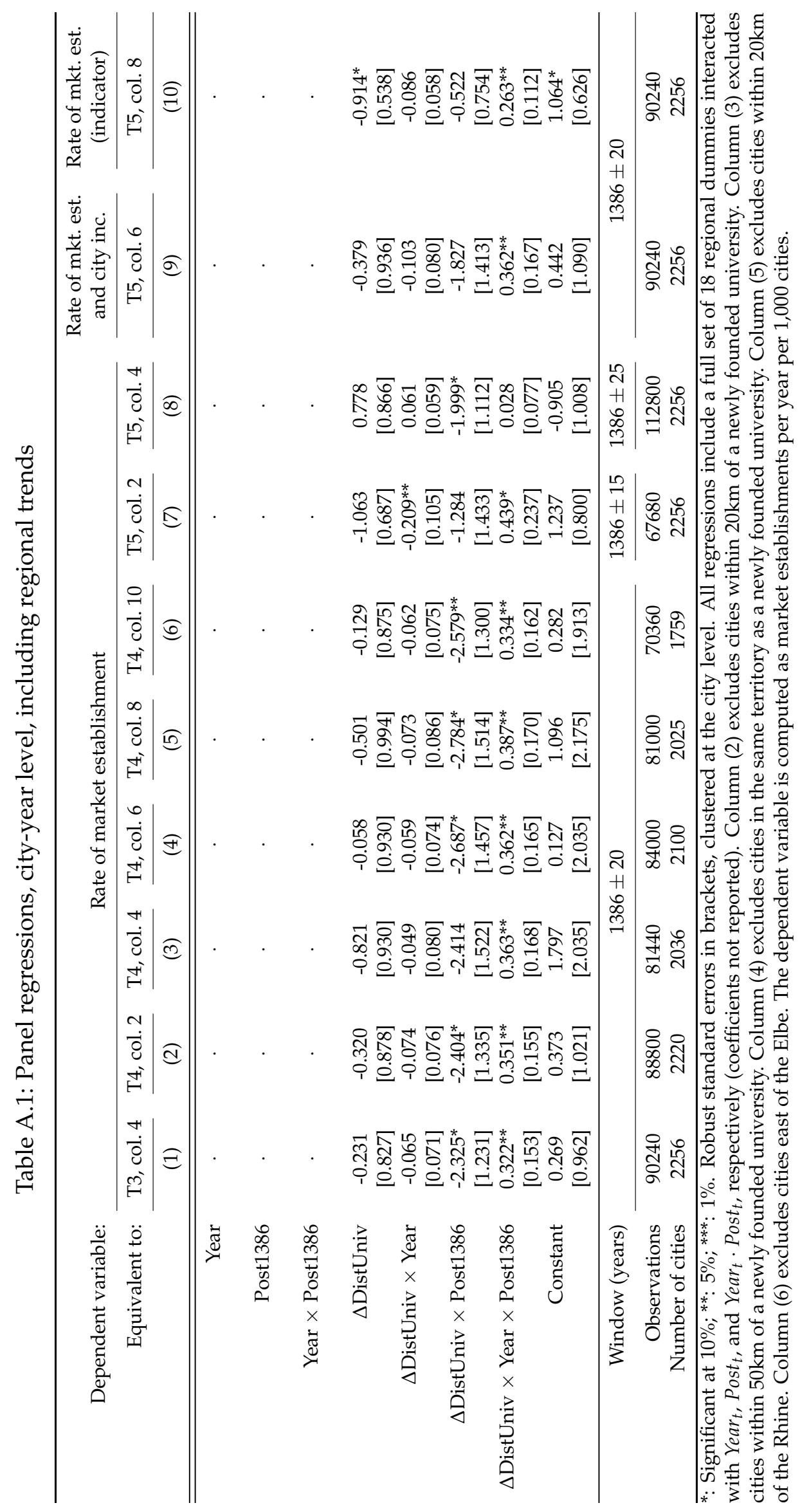




\section{A.2 Units of analysis and clustering city-year level regressions at the territory level}

As noted in the text, our choice of city-year as the unit of analysis raises concerns about the statistical inferences we make (i.e., how many independent observations we have) and general equilibrium effects (i.e., the possibility that units' interdependence biases our coefficients). In this section we replicate our panel regressions from Tables 4 and 5, but using different units of analysis, or clustering our standard errors at different levels.

We first, in Table A.2, present results from estimating specifications presented in Tables 4 and 5, but using territory-year as the unit of analysis. One can see that our results are extremely similar to those presented in the main text. We do lose some power, but our statistical inferences are quite robust.

Next, we estimate the same specifications, but using cell-year as the unit of analysis. One can see that our results are again very similar to those presented in the main text (see Table A.3).

Finally, we estimate the specifications presented in Tables 3-5 using city-year data as in the text, but clustering our standard errors at the territory level to account for possibly correlated

error terms across observations in an entire territory, across space or time. One can see that the magnitudes of the standard errors and our statistical inferences are largely unchanged using this specification (see Table A.4). 


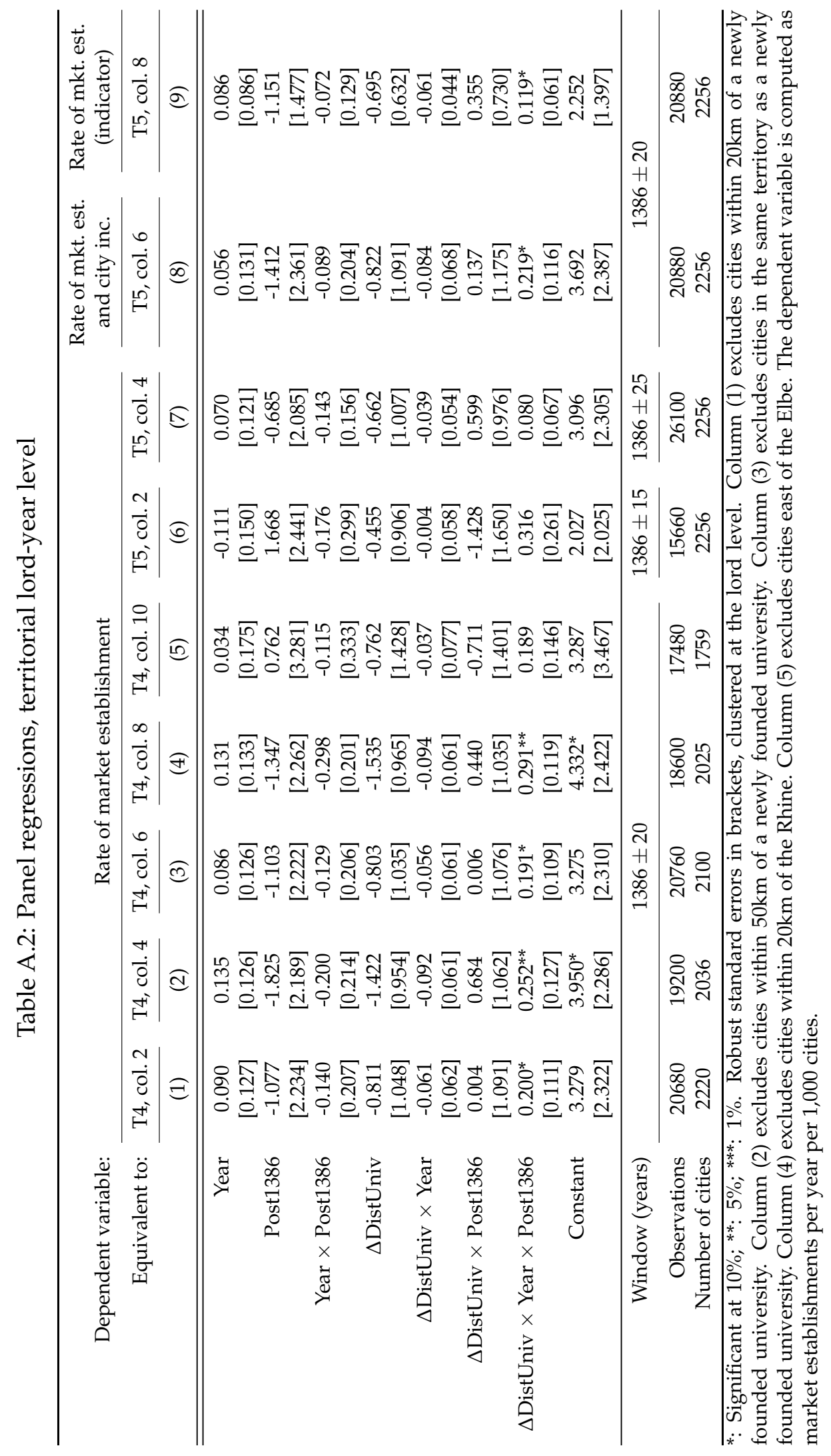




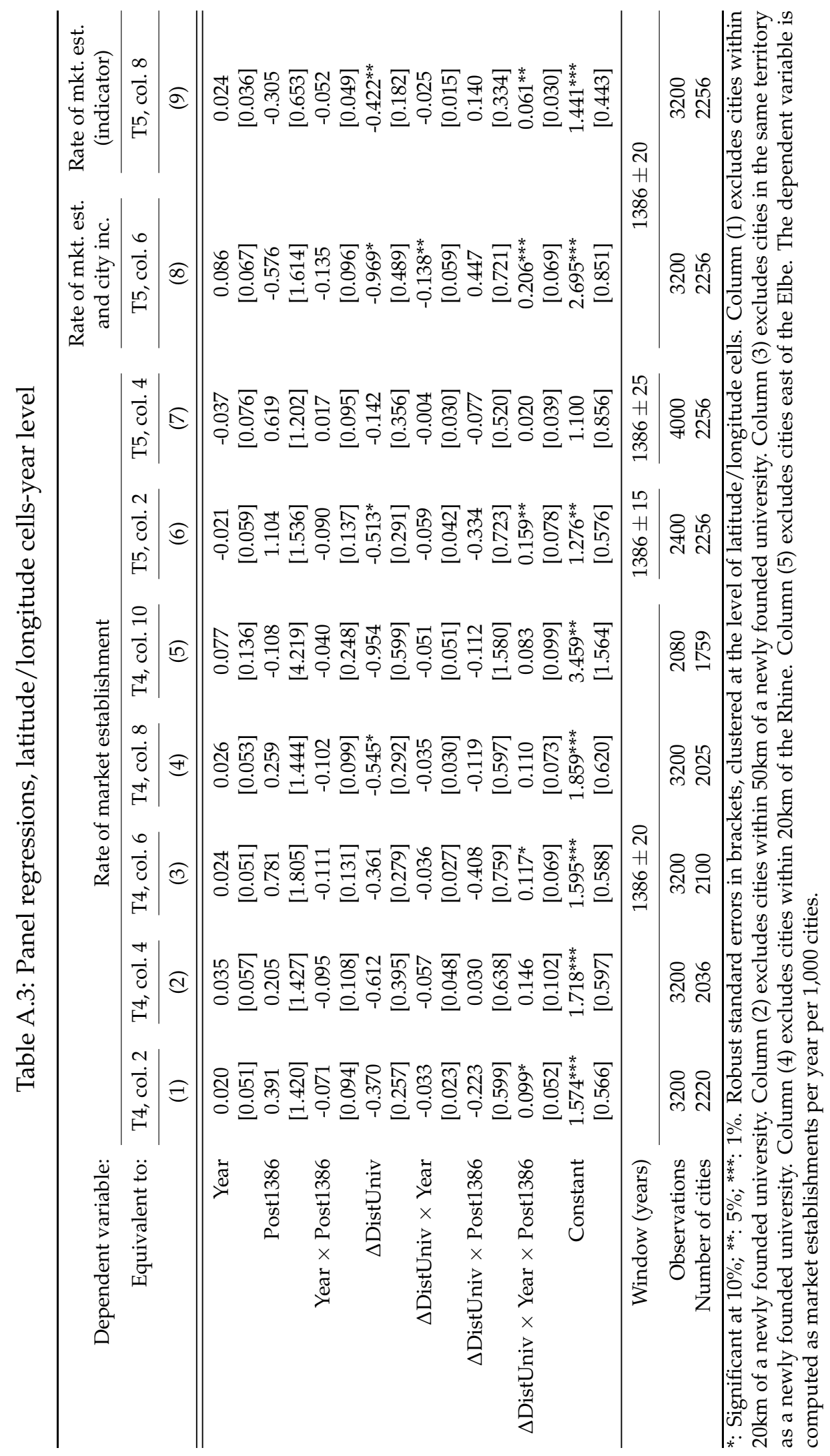




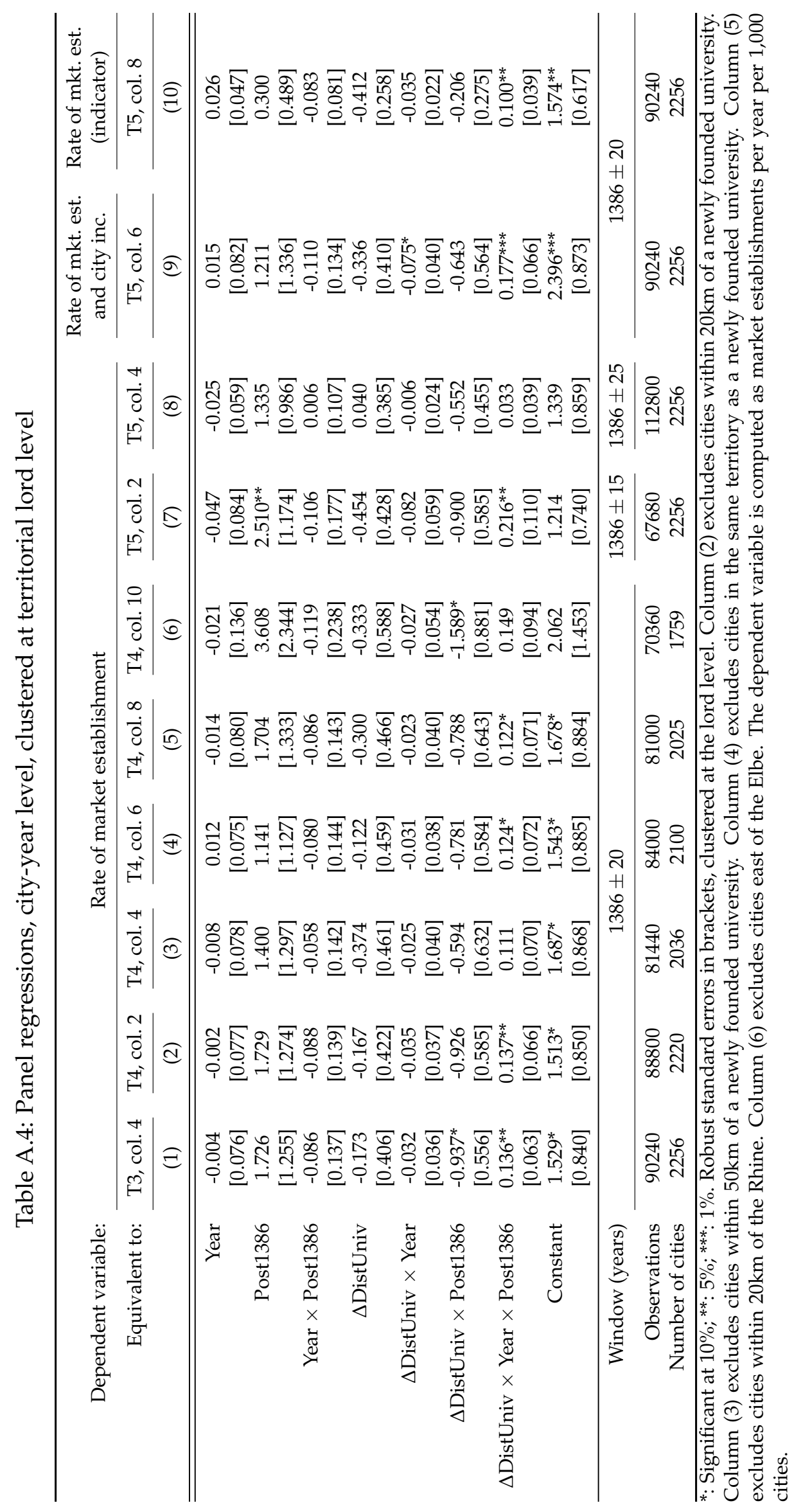




\section{A.3 Above/below median split sample results for spatial endogeneity, robustness re- sults, and placebo regressions.}

Our baseline results in Table 3 indicated that Germany experienced a break in the trend rate of market establishment in 1386; that this break was concentrated in cities with a change in distance to a university in 1386 greater than the median; and, we saw that in panel regressions, there was a significantly greater trend break in places with larger reductions in distance to a university in 1386.

Because our panel regression contained much of the information presented in the split sample results, we omitted many of the latter from the main text. Here, we present the omitted regressions from Tables 4 and 5.

One can see that our time-series evidence, showing a break in the trend rate of market establishment for all of Germany, was indeed driven by trend breaks specifically in areas with changes in distance to a university in 1386 that were greater than the median (see Table A.5). This is true across specifications, providing further evidence in support of our hypothesis that increased access to universities after 1386 significantly affected economic activity.

Moreover, in Figures A.1 and A.2 we report the same placebo analysis of Figure 8 (examining the effect of varying the year defining the Post $_{t}$ dummy from 1376 to 1396) separately for the samples of cities above and below median $\Delta$ DistUniv. Again, one can see that there is a break in trend concentrated on the years around 1386 for the cities with a large change in distance to a university, but no significant break in trend for any of the years 1376-1396 in the sample of cities below median $\Delta$ DistUniv. 


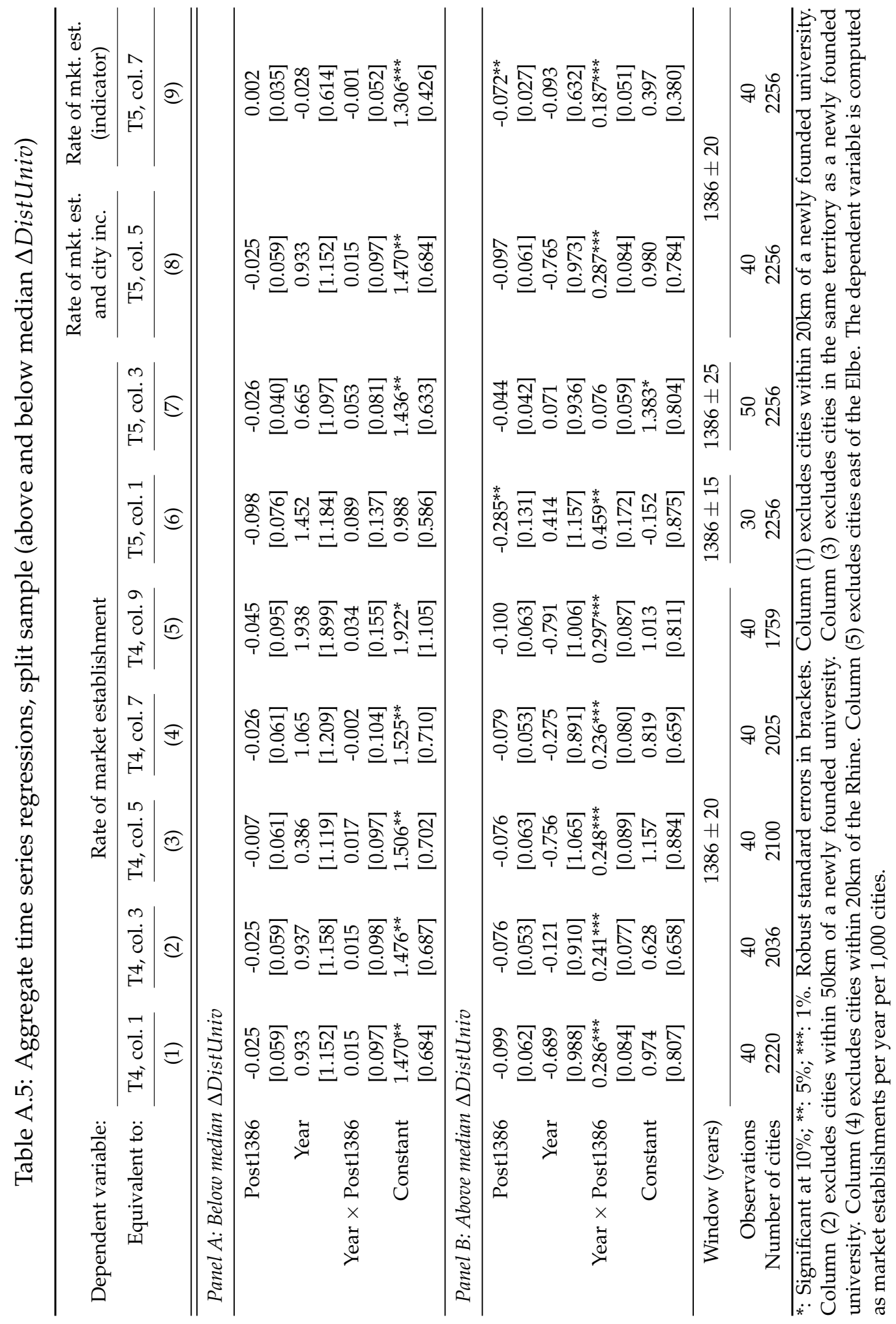




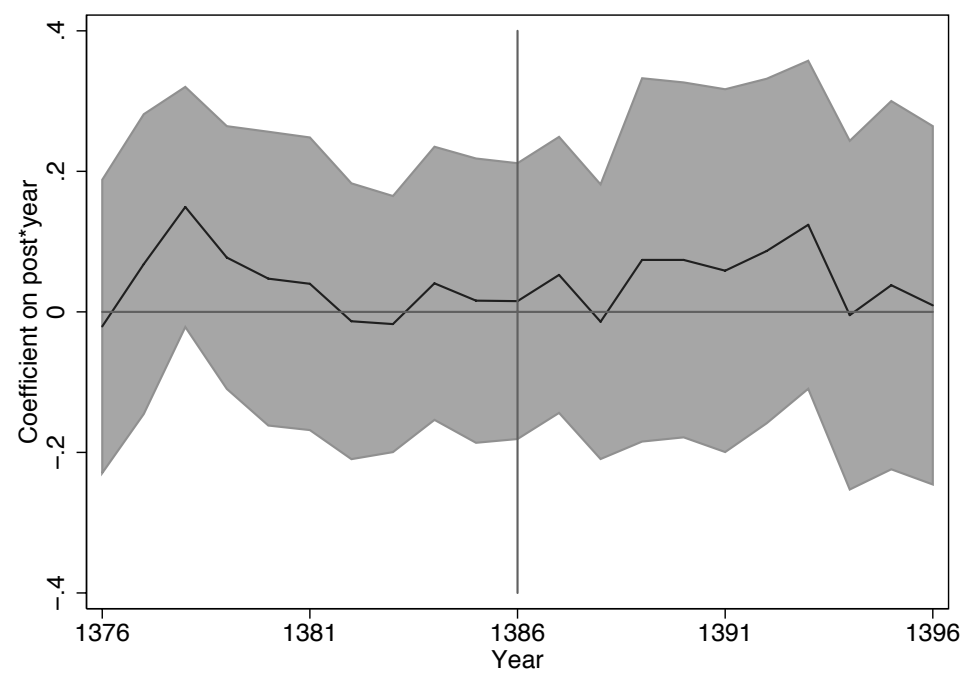

Figure A.1: Changes in the trend rate of market establishment, cities with small (below median) $\Delta$ DistUniv (coefficient on Year $_{t} \cdot$ Post $_{t}$ ) under varying pivot years, 1376-1396

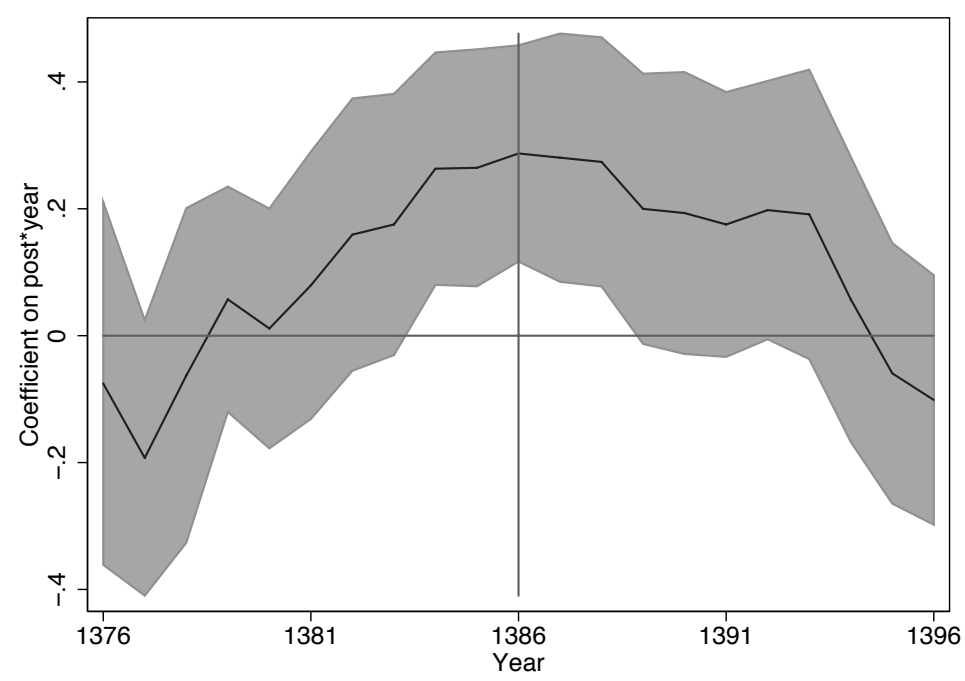

Figure A.2: Changes in the trend rate of market establishment, cities with large (above median) $\Delta$ DistUniv (coefficient on Year $_{t} \cdot$ Post $_{t}$ ) under varying pivot years, 1376-1396 


\section{A.4 England and Italy 1378 pivot year}

Our test for a break in the trend rate of market establishment in Italy or England and Wales in 1386 was intended to check whether places experiencing the Schism, but not experiencing university foundations as a result, also experienced changed rates of market establishment.

Of course, the pivot year we used was chosen to fit specifically German circumstances (the slight delay between the year of the Schism and the foundation of Germany's first universities). If the Papal Schism affected market establishment in England and Wales or in Italy, it might have done so immediately. We thus estimate the specifications in Table 6, but use 1378 as the pivot year used to define Post . We again find no effect of the Papal Schism on market establishment in England and Wales or in Italy, suggesting that without university establishment as a consequence, the Papal Schism did not significantly affect economic activity (see Table A.6).

Table A.6: Robustness of placebo analyses

\begin{tabular}{|c|c|c|}
\hline \multirow{3}{*}{$\begin{array}{r}\text { Dependent variable: } \\
\text { Sample: }\end{array}$} & \multicolumn{2}{|c|}{ Rate of market establishment } \\
\hline & Italy & $\begin{array}{l}\text { England } \\
\text { and Wales }\end{array}$ \\
\hline & (1) & (2) \\
\hline Year & $\begin{array}{c}-0.087 \\
{[0.064]}\end{array}$ & $\begin{array}{c}-0.020 \\
{[0.034]}\end{array}$ \\
\hline Post1378 & 2.161 & $1.742^{*}$ \\
\hline Year $\times$ Post1378 & $\begin{array}{c}{[1.373]} \\
0.119 \\
{[0.145]}\end{array}$ & $\begin{array}{c}{[0.954]} \\
-0.079 \\
{[0.072]}\end{array}$ \\
\hline Window (years) & \multicolumn{2}{|c|}{$1378 \pm 20$} \\
\hline $\begin{array}{l}\text { Observations } \\
\text { Number of cities }\end{array}$ & $\begin{array}{c}40 \\
190\end{array}$ & $\begin{array}{c}40 \\
2254\end{array}$ \\
\hline $\begin{array}{l}\text { gnificant at } 10 \% \text {; } \\
\text { rs in brackets. The } \\
\text { arket establishmel }\end{array}$ & $5 \%{ }^{*}$ & Robust sta \\
\hline
\end{tabular}

